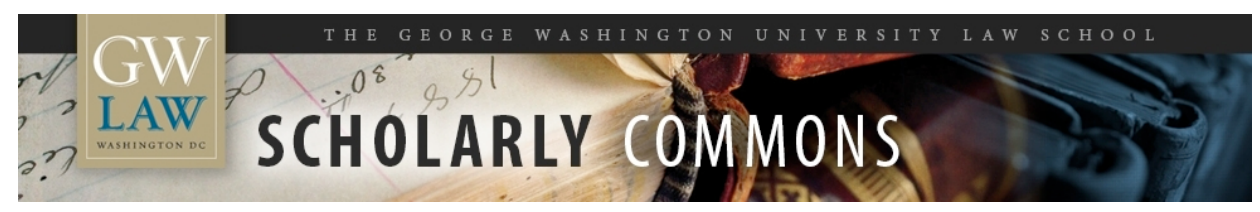

\title{
Intergenerational Justice Between Authors in the Digital Age
}

Dawn C. Nunziato

George Washington University Law School, dnunziato@law.gwu.edu

Follow this and additional works at: https://scholarship.law.gwu.edu/faculty_publications

Part of the Law Commons

\section{Recommended Citation}

Dawn C. Nunziato, Intergenerational Justice Between Authors in the Digital Age, 9 J. Intell. Prop. L. (2002).

This Article is brought to you for free and open access by the Faculty Scholarship at Scholarly Commons. It has been accepted for inclusion in GW Law Faculty Publications \& Other Works by an authorized administrator of Scholarly Commons. For more information, please contact spagel@law.gwu.edu. 


\title{
Intergenerational Justice Between Authors in the Digital Age
}

\author{
By Dawn C. Nunziato ${ }^{1}$
}

\section{Introduction}

Authors' copyright rights have traditionally been limited, because such limitations were believed to be necessary to advance copyright law's constitutionally-mandated utilitarian purpose -- "to promote the progress of science and the useful arts." ${ }^{2}$ But authors today - especially authors of digital works - are increasingly turning to extracopyright measures, including encryption and "clickwrap" licenses, to customize their rights in their works of authorship. Because such privately-ordered rights are (arguably) outside of copyright law's framework, they are not necessarily subject to its utilitarian mandate, and need not be made subject to limitations imposed by copyright law on authors' rights. Yet even though such private ordering regimes may not be subject to copyright law's utilitarian mandate justifying limitations on authors' rights, other powerful justifications implicit in the copyright regime support the imposition of limitations on authors' rights. In this Article, I advance one such theoretical justification. Building upon the foundational work of John Rawls, who has articulated a theory of justice as "fairness," I develop a theory of justice between generations of authors. This theory requires that the rights of each generation of authors - including the rights that they might attempt to assert through private ordering measures - be limited for the benefit of subsequent generations of authors.

\footnotetext{
${ }^{1}$ Assoc. Professor of Law, The George Washington University Law School. B.A., University of Virginia; M.A. (Philosophy), University of Virginia; J.D., University of Virginia. I am grateful to Robert Brauneis, David Post, Roger Schechter, Peter Swire, and to the participants in The George Washington University Law School and University of Virginia School of Law works-in-progress series, for their comments on this Article.
} 
While not limited to authors' rights in digital works, the theory of intergenerational justice between authors that I advance is particularly relevant to the burgeoning private ordering regime, in which authors of digital works are increasingly using private ordering measures to create for themselves virtually unlimited rights - in disregard of the interests of future generations of authors - even while they are benefiting from the limitations copyright law has imposed on the rights of their predecessor generation of authors. Authors of electronic books, for example, are increasingly using "clickwrap" licenses and encryption controls to prohibit their readers from copying any portion of their books, even while these authors have benefited from incorporating elements of earlier works into their own works. Motion picture companies are increasingly using technological measures like encryption devices to control access to and copying of their films released on DVD, even while the filmmakers have benefited from copying elements of earlier works in developing their films. By the use of such private ordering measures, present-day authors are able to reap the benefits of the limitations on authors' rights previously imposed by copyright law, while casting aside any limitations on their rights for the benefit of future authors. I contend that the use of such private ordering measures to establish unlimited rights in creative works is inconsistent with intergenerational justice obligations imposed upon authors to preserve the raw materials of the creative process for the benefit of future generations of authors.

In Part I of this Article, I set forth the principal tenets of a general theory of intergenerational justice, drawing from the work of John Rawls. As part of his general theory of justice as fairness, Rawls outlines a theory of justice between generations and a

\footnotetext{
${ }^{2}$ The Constitution empowers Congress to enact copyright and patent statutes "to promote the progress of science and the useful arts." U.S. Const., art. I, § 8, cl. 8.
} 
"just savings" principle according to which the generation into which one is born is and should be rendered morally irrelevant. Under this theory of justice between generations, the distribution of benefits and burdens made available by cooperation in society is to be determined without reference to an individual's temporal priority along the timeline of society. In particular, individuals deliberating in a Rawlsian "original position" are charged with choosing a principle of intergenerational savings that they would want all previous generations to have followed (and later generations to follow), no matter how far backward or forward in time. Regulated by a principle of intergenerational savings, individuals within each generation are obliged to forgo immediate gains that are available to them where necessary to protect the interests of future generations.

Although intergenerational justice concerns have frequently animated debates in the environmental sphere, such concerns have yet to be articulated in the intellectual property arena. In Part II, I apply the general principles of intergenerational justice articulated in Part I to intellectual property rights in creative works. In Part II(A), I explore the interests and motivations of authors in an initial choice situation where no information is available to them as to which generation along the timeline of society they belonged. I contend that, behind such a Rawlsian veil of ignorance, authors would opt for a system of required savings of creative works, which would translate into substantial limitations on authors' rights in their works. Because authors deliberating in this initial choice situation would not know whether they belonged to an earlier or later creative generation and because such authors would likely believe that the creative process entails the incorporation of some elements and uses of predecessors' works, they would find it in their interests to limit authors' rights in their creative works across the board. In 
exploring the interests and incentives operating upon authors deliberating behind the veil of ignorance, I consider in Part II(B) the economic analysis of authors' rights advanced by William Landes and Richard Posner. Landes and Posner's analysis, while emanating from a different theoretical framework, provides further support for the claim that authors would agree ex ante to limitations on their rights for the benefit of the creative enterprise in the long run.

In Part II(C), I anticipate and address some objections to this theory of intergenerational justice in general and mandated intergenerational savings of elements of creative works in particular. Richard Epstein, for one, contends that any system of mandated intergenerational savings is inferior to an unfettered market based on strong property rights in which we simply rely upon individuals' natural predisposition to save for the benefit of their progeny. While Epstein may be correct that we can and should generally rely upon individuals' natural inclinations to save for their progeny, I contend that such reliance is likely to be inadequate with respect to the particular case of intergenerational savings by authors for the benefit of subsequent authors.

In Part III, I take a fresh look at the limitations historically imposed by copyright law on authors' rights from the perspective of intergenerational justice between authors. Although Congress and the courts have not explicitly adverted to principles of intergenerational justice in justifying limitations on creators' rights, such themes can be seen to inhere in the jurisprudence of copyright limitations. Specifically, the limitations imposed on the term of copyright protection, as well as limitations imposed by copyright law's idea/expression dichotomy and fair use doctrine, have the effect of mandating the "savings" of certain elements and uses of the creative process for the benefit of future 
authors, at the expense of present authors. In myriad circumstances in which authors have sought to wield their exclusive rights in ways that would fail to preserve the raw materials of the creative process for subsequent generations of authors, copyright law has imposed significant limitations on creators' rights. Because present authors acting in their own interests do not have sufficient incentive to "save" for the benefit of future authors, copyright law has traditionally mandated the savings of certain elements and uses of authors' creative works for the benefit of future authors.

As I explore in Part IV, however, private ordering regimes for structuring authors' rights, including those enabled by technological and contractual measures, embody no similar mandate of intergenerational savings. With the use of technological measures such as encryption controls that prohibit any and all copying of encrypted creative works, and of "clickwrap" licenses that create perpetual rights in works and require users to waive their fair use and other rights in such works, we are transitioning into a regime in which the present generation of authors can benefit from the intergenerational savings scheme previously embodied in copyright law, without in turn having to suffer limitations on their own rights for the benefit of subsequent authors. Within the incipient private ordering regime, each creator is able to decide for herself, using her private calculus of benefits and harms, how to design her rights in her creative work, including whether to permit subsequent authors to make use of any portion of her work. The danger thus arises that present authors will choose to maximize their returns on their creative works at the expense of subsequent generations of authors, whose interests will not be adequately taken into account. By enabling each author essentially to determine 
for herself the scope and duration of her rights, private ordering regimes fail to account for the interests of future generations of authors.

In the recently enacted Digital Millennium Copyright Act, ${ }^{3}$ Congress empowered authors to use technological measures, such as encryption controls, to create for themselves virtually unlimited rights in their works. Although such rights are subject to minor limitations, these limitations are insufficient to protect the interests of future generations of creators, as I discuss in Part IV(A). Furthermore, authors are increasingly resorting to contractual measures, such as clickwrap licenses, to create for themselves broad, perpetual rights in their works. A newly promulgated uniform statute - the Uniform Computer Information Transactions $\mathrm{Act}^{4}$ - already adopted in several states, provides a framework for the creation of broad, perpetual rights in certain types of creative works. And courts that have been called upon to enforce essentially unlimited contractual rights for authors generally have been unwilling to read any limitations into such privately ordered rights, as I discuss in Part IV(B).

Finally, in Part V, I contend that in order to carry forth into the digital realm the commitment to justice between generations of authors that is implicit in the copyright regime, Congress and the courts should continue to impose substantial limitations on authors' rights, whether protected by public or private ordering measures. Although the migration of creative works to the digital realm may require some recalibration of the limitations historically imposed on creators' rights, intergenerational justice concerns require that the interests of future generations of authors should be protected, as they

\footnotetext{
${ }^{3}$ Pub. L. No. 105-304, 112 Stat. 2860, Section 1 (short title).

${ }^{4}$ Unif. Computer Info. Transactions Act (Sept. 29, 2000) (hereinafter UCITA). All drafts of UCITA are available from the Uniform Law Commissioner's official site at http://www.law.upenn.edu/bll/ulc/ulc_frame.htm.
} 
traditionally have been in the copyright regime, by mandating savings of components of earlier authors' creative works. Toward this end, I propose several ways in which limitations should be imposed on authors' privately ordered rights so as to embody a form of intergenerational justice between authors in the digital age.

\section{TOWARD A GENERAL THEORY OF INTERGENERATIONAL JUSTICE}

\section{A. Introduction}

The subject of intergenerational justice, while touched upon in the works of theorists over the past several centuries, ${ }^{5}$ has been explicitly examined only recently. ${ }^{6}$ Theorists throughout the centuries exploring issues of distributive justice have primarily focused on the subject of intragenerational justice - that is, how to establish a just social system for allocating the benefits and burdens of social cooperation among individuals existing in society at any given time and belonging roughly to the same generation. ${ }^{7}$ Beginning in the 1950s and 60s, however, theorists focusing on issues such as the mistreatment of non-renewable environmental resources, the rapid growth of the world

\footnotetext{
${ }^{5}$ Throughout the past centuries, only a handful of thinkers have hinted at the issue of intergenerational justice. Edmund Burke, writing in 1790, opined that:

Society is indeed a contract ... . a partnership in all art, a particular in every virtue, and in all perfection. As the ends of such a partnership cannot be obtained in many generations, it becomes a partnership not only between those who are living, but between those who are living, those who are dead, and those who are to be born.
}

EDMUND BuRKe, REFLECTIONS ON THE REVOLUTION IN FRANCE (1790). Nineteenth Century philosopher Henry Sidgwick also alluded to concerns of intergenerational justice, when he asked: "How far are we to consider the interests of posterity when they seem to conflict with those of existing human beings? ... [T] he time at which a man exists cannot affect the value of his happiness from a universal point of view; and . . . interests of posterity must concern a utilitarian as much as those of his contemporaries ...." HENRY SIDGWICK, THE METHODS OF ETHICs 385 (MacMillan 1962).

${ }^{6}$ See generally Peter LASLetT \& JAMES S. FishKin, Justice BetweEn Age GROUPS AND GENERATIONS 1-23 (1992). 
population, and the funding of an ongoing system of social security, began to consider whether and to what extent concerns of intergenerational justice served to impose limitations on the rights of those in the present generation in the interests of those to be born into future generations. ${ }^{8}$ Such intergenerational theories of justice examined whether and how the rights of those in present generations should be limited to safeguard the interests of those in generations to come. ${ }^{9}$

In essence, the intergenerational justice inquiry sets off in two directions. First, from the perspective of the present generation, we may ask, what is it reasonable for us to expect from the previous generation - in the way of sacrifices made on our behalf, either in the form of savings for our benefit or actions taken to prevent harm from being visited upon our generation. Prospectively, the question becomes, what limitations on our rights would be reasonable to impose in the interests of generations to come? For all but the very first and last generations in the timeline of society, the intergenerational justice inquiry is both forward-looking and backward-looking, and can be structured as a hypothetical tripartite contract between (1) the present generation; (2) the preceding generation(s); and (3) the succeeding generation(s). As Peter Laslett observes regarding the structure of this tripartite contract, "If each successive generation is regarded as having both rights and duties, then the rights that any given generation (here generation 2) has in its predecessor (generation 1) are met by the duties it performs for its successor

\footnotetext{
${ }^{7}$ See generally Laslett \& Fishkin, supra note 6, at 14-22.

${ }^{8}$ See, e.g., Martin Golding, Ethical Issues in Biological Engineering, 15 U.C.L.A. L. REV. 443 (1968); Martin Golding, Obligations to Future Generations, 56 MONIST 85 (1972); R. I. SIKORA AND BRIAN BARRY, EDS., OBLIGATIONS TO FUTURE GENERATIONS (1978); JOHN RAWLS, A THEORY OF JUSTICE (1971).

${ }^{9} I d$.
} 
(generation 3). [As such], the rights a generation has in preceding generations are matched by the duties that have to be performed toward generations yet to come." 10

\section{B. Intergenerational Justice and Rawls' Theory of Justice}

In developing the outlines of a general theory of intergenerational justice, I begin with John Rawls' groundbreaking treatment of this subject in his 1971 treatise $A$ Theory of Justice. ${ }^{11}$ In order to benefit from Rawls' substantial contributions toward a theory of intergenerational justice, it will be necessary to first review the fundamental elements of Rawls' theory of justice, which he denominates "justice as fairness." 12 After briefly reviewing the basic structure of Rawls' theory of justice, I then focus in detail on Rawls' treatment of intergenerational justice and intergenerational savings in particular.

\section{The Subject of Justice in A Theory of Justice}

The primary subject of Rawls' theory of justice as fairness is that of social justice - i.e., the manner in which the major social institutions distribute fundamental rights and duties and determine the division of advantages and disadvantages that result from social cooperation. ${ }^{13}$ According to Rawls, justice is and must be conceptualized as the most important virtue of the major social institutions. ${ }^{14}$ If a social institution is not just, it must be restructured or reformulated to render it just. ${ }^{15}$ The major social institutions that comprise the subject of justice include the principal economic and social arrangements of

\footnotetext{
${ }^{10}$ Laslett \& Fishkin, supra note 6, at 26.

${ }_{11}^{11}$ JOHN RAWLS, A THEORY OF JUSTICE (1971).

${ }^{12} \mathrm{Id}$. at 3 .

${ }^{13} \mathrm{Id}$. at 4-7. See also id. at 54-58.

${ }^{14} \mathrm{Id}$. at 3.

${ }^{15} \mathrm{Id}$. at 3.
} 
society, including the legal protection of freedom of thought, freedom of conscience, and

- notably for our purposes -- systems of property. ${ }^{16}$ Given that intellectual property is an increasingly significant component of the private property system, it is worthwhile to explore the implications of justice as fairness in general - and intergenerational justice in particular -- for systems of intellectual property.

\section{The Original Position and the Two Principles of Justice}

Rawls first attempts to derive a set of principles for assigning the rights and duties in the major social institutions and for defining the appropriate distribution of the benefits and burdens that result from social cooperation. ${ }^{17}$ He expounds a theory of an initial position of equality among individuals in society by elaborating upon and "carry[ing] to a higher level of abstraction" the social contract - the traditional expository device of political philosophers. ${ }^{18}$ Generalizing from earlier social contract theories, Rawls develops a theory of an initial choice situation in order to elicit the principles that free and rational persons concerned to further their own interests would accept in an initial position of equality defining the fundamental terms of their association. ${ }^{19}$ In developing a theory of justice and exploring the fair terms of social cooperation, Rawls first imposes certain limits or constraints on arguments in the initial choice situation that embody the foundational elements of justice as fairness. The "original position" - the most favorable

\footnotetext{
${ }^{16}$ Id. at 7,55 .

${ }^{17} I d$. at $4-5$.

${ }^{18}$ Rawls presents a conception of justice as fairness that "generalizes and carries to a higher level of abstraction the familiar theory of the social contract," $i d$. at 11, as found in the theories of political philosophers such as Locke, Rousseau, and Kant. Within Rawls' theory, the original position of equality corresponds to the state of nature in the traditional theory of the social contract. Id. at 12.

${ }^{19} I d$. at 11 .
} 
interpretation of the initial situation ${ }^{20}-$ is an expository device that imposes certain constraints on arguments for arriving at the fair terms of social cooperation. These constraints are imposed by virtue of the "veil of ignorance," ${ }^{21}$ behind which individuals formulate arguments and deliberate regarding the principles of justice, and behind which it is not possible for individuals to tailor the principles of justice to favor their own social or natural circumstances. Thus, behind the veil of ignorance, in bargaining over the proper distribution of the benefits and burdens resulting from social cooperation, individuals cannot know their place in society, class position, social status, race, gender, intelligence, strength, or other aspects of their fortune in the distribution of natural or social assets or abilities. ${ }^{22}$ Nor can they know their own detailed conception of the good or particulars of their rational plans of life. ${ }^{23}$ Given this lack of knowledge regarding individual features and characteristics, no one in the original position can design the principles of justice to favor his or her particular conditions or circumstances. ${ }^{24}$ Knowledge of such characteristics is shielded from the individuals deliberating behind the veil of ignorance because such social and natural circumstances are morally irrelevant from the perspective of justice as fairness. ${ }^{25}$ The veil of ignorance is therefore designed to embody the constraint that these occluded features and characteristics are irrelevant, and therefore should be made irrelevant, from the standpoint of justice. ${ }^{26}$

\footnotetext{
${ }^{20}$ Rawls defines the original position as the "interpretation of the initial situation that best expresses the conditions that are widely thought reasonable to impose on the choice of principles yet which, at the same time, leads to a conception that characterizes our considered judgments in reflective equilibrium." Id. at 121 .

${ }^{21} I d$. at 18.

${ }^{22} I d$. at $136-42$.

${ }^{23} \mathrm{Id}$. at $136-37$.

${ }^{24} \mathrm{Id}$. at 139 .

${ }^{25} \mathrm{Id}$. at 141.

${ }^{26} \mathrm{Id}$.
} 
The original position serves as an expository device that sums up the meaning of the conditions we would be prepared to impose on arguments in formulating principles of justice that will define the distribution of benefits and burdens resulting from social cooperation. $^{27}$ In Rawls' words:

We can, as it were, enter [the original position] at any moment simply by conducting our moral reasoning about first principles in accordance with the stipulated procedural constraints. .. . [The original position] is an attempt to represent and unify the formal and general elements of our moral thought in a manageable and vivid construction in order to use these elements to determine which first principles of justice are the most reasonable. ${ }^{28}$

The constraints in the original position are those that we would be prepared to regard as limits on the fair terms of social cooperation. ${ }^{29}$ As a result, the principles of justice that are chosen in the original position are those that "rational persons concerned to advance their own interests would consent to as equals, where none are known to be advantaged or disadvantaged by social or natural contingencies."30

As discussed above, many features of the deliberating parties' social and natural characteristics are hidden from them in the initial choice situation. However, in order to "generate the minimal motivations necessary to get a problem of rational choice going,"31 the deliberating parties need to have some information available to them. Accordingly, the individuals in the original position do know that they are motivated to increase their share of "primary social goods",32 -- i.e., rights and liberties, opportunities and powers, income and wealth ${ }^{33}$ - goods that will enable them to promote their own particular

\footnotetext{
${ }^{27} I d$. at 21.

${ }^{28}$ JoHn RAWLS, POLITICAL LiBERALISM 275 (1993). See also Rawls, supra note 11, at 19, 138.

${ }^{29}$ Rawls, supra note 11 , at 21.

${ }^{30} I d$. at 19.

${ }^{31}$ See Michael SANDEL, Liberalism AND the Limits of Justice 25 (1982).

${ }^{32}$ Rawls, supra note 11, at 142-44.

${ }^{33}$ Id. at 92-93.
} 
conception of the good most effectively, whatever it turns out to be. ${ }^{34}$ Further, the individuals deliberating behind the veil of ignorance are rational and mutually disinterested $^{35}$ - i.e., they do not take an interest in one another's interests and are not motivated to advance the well-being of other individuals in society. ${ }^{36}$ Rawls stipulates further that the deliberating parties are risk-averse and concerned to minimize their worst possible outcomes. ${ }^{37}$ They also know that their society is subject to the circumstances of justice - i.e., that many individuals coexist together in a definite geographical territory, that their society is subject to moderate scarcity, and that they are capable of a sense of justice. $^{38}$ Finally - and importantly for the subject of intergenerational justice - Rawls posits, consistent with his present time of entry interpretation, ${ }^{39}$ that the individuals deliberating behind the veil know that they are contemporaries - all belonging to the same generation - although they do not know the particular circumstances of their own society, the level of culture it has been able to achieve, or to which generation in particular they belong. ${ }^{40}$ The parties deliberating behind the veil of ignorance "must choose principles the consequences of which they are prepared to live with whatever generation they turn out to belong to." ${ }^{41}$

Having set forth the circumstances of the original position as constraints on the deliberating parties' arguments, Rawls then establishes that the parties would select the

\footnotetext{
${ }^{34} I d$. at 144.

${ }^{35} \mathrm{Id}$. at 139.

${ }^{36} I d$. at 13 .

${ }^{37} I d$. at $152-61$.

${ }^{38} \mathrm{Id}$. at $126,137,145$.

${ }^{39} \mathrm{Id}$. at 140 .

${ }^{40} I d$. at 136.

${ }^{41} I d$.
} 
following two fundamental principles of justice, ${ }^{42}$ to be ranked and applied in "lexical order": 43

each person is to have an equal right to the most extensive total system of equal basic liberties compatible with a similar system of liberty for all; and

social and economic inequalities are to be arranged so that they are both (a) to the greatest benefit of the least advantaged, consistent with the just savings principle, and (b) attached to offices and positions open to all under conditions of fair equality of opportunity. ${ }^{44}$

These two principles dictate that "all primary social goods are to be distributed equally unless an unequal distribution of any or all of these goods is to the advantage of the least favored, ${ }^{45}$ consistent with the just savings principle.

\section{The Principle of Intergenerational Justice and the Just Savings Principle}

As discussed above, in A Theory of Justice Rawls provides the first extended treatment of the subject of intergenerational justice, which he characterizes as among the most difficult of the issues confronting any theory of justice. ${ }^{46}$ In setting out the basic contours of the principle of justice between generations, Rawls contends, first, that the generation into which an individual is born is morally irrelevant from the perspective of social justice: "In first principles of justice we are not allowed to treat generations differently solely on the grounds that they are earlier or later in time."47 Therefore, the major social institutions, including systems of property - and for our purposes, systems of intellectual property -- must be structured so as to reflect this moral irrelevance.

\footnotetext{
${ }^{42} I d$. at 219.

${ }^{43} I d$. at $61,63,302$.

${ }^{44} I d$. at 60,302 .

${ }^{45} \mathrm{Id}$. at 303.

${ }^{46}$ Rawls states that the problem of justice between generations subjects any ethical theory to "severe if not impossible tests," $i d$. at 284 , but that an account of distributive justice would be incomplete without a discussion of this subject. Id.
} 
Whether an individual is born in 1950 or 2050 should not affect that individual's distribution of rights and liberties, opportunities and powers, income and wealth. Rather, we must view the life of a people as a "scheme of cooperation spread out in historical time, ... [which] is to be governed by the same conception of justice that regulates the cooperation of contemporaries. [As such], no generation has stronger claims than any other [to distribution of primary social goods]. ${ }^{\prime 48}$ Thus, the first important component of Rawls' principle of intergenerational justice is that the temporal priority of individuals i.e., when they arrive on the timeline of society - entails no moral priority, and should be made morally irrelevant in structuring the major social institutions, including, for our purposes, systems of intellectual property.

Because an individual's temporal priority - like her gender, race, wealth, etc. -- is morally irrelevant within Rawls' theory of intergenerational justice, one might suppose Rawls would design the circumstances of the original position so as to obscure from the deliberating parties knowledge about which generation they belong to. If one's generational association along the timeline of society were obscured behind the veil of ignorance, a deliberating party would not be permitted to adopt principles tending to favor his generation, because he would not know to which generation he belonged. Rawls, however, consistent with his "present time of entry" interpretation, ${ }^{49}$ rejects the idea of conceptualizing the original position as a "general assembly which includes at one moment everyone who will live at some time [or] . . . as an assembly of everyone who

\footnotetext{
${ }^{47}$ Id. at 295.

${ }^{48} I d$. at 289.

${ }^{49} I d$. at 140 .
} 
could live at some time." ${ }^{50}$ Instead, he chooses to design the original position such that the deliberating parties know that they are contemporaries - all belonging to the same generation. $^{51}$

Because Rawls structures the original position such that the parties deliberating in the original position know that they belong to the same generation, it is possible that the parties would choose to disregard the interests of their successor generations - since no one in the original position represents the interests of successor generations and since the deliberating parties have an incentive to maximize their (and their generation's) share of primary social goods. ${ }^{52}$ Yet, Rawls intends to design the circumstances of the original position to reflect the principle that no generation has stronger claims than any other as to the distribution of primary social goods. The deliberating parties' knowledge that they all belong to the same generation thus presents a theoretical difficulty with respect to the design of the circumstances of the original position to generate principles that reflect concerns of intergenerational justice. Put another way, Rawls intends to structure the circumstances of the original position such that earlier generations will not choose principles for distributing the benefits and burdens of social cooperation in disregard of the interests of subsequent generations, and in particular, so that members of earlier generations will bind themselves to save for the benefit of subsequent generations. However, because the deliberating parties in the original position know that they all belong to the same generation, adopting a savings principle can only hurt them. ${ }^{53}$ This

\footnotetext{
${ }^{50} I d$. at 292,139 . Such an interpretation would "stretch fantasy too far [such that] the conception would cease to be a natural guide to intuition." Id. at 139.

${ }^{51} I d$. at 139.

${ }^{52}$ Recall that the parties in the original position are presumed to be rational and mutually disinterested. See text accompanying notes 35-36.

${ }^{53}$ Rawls, supra note 11, at 292.
} 
presents the complication that, in arriving at the principles of justice and designing the major social institutions, the deliberating parties might choose to favor their own generation and decline to make any sacrifices at all for their successors. ${ }^{54}$

Rawls first attempts to deal with this theoretical difficulty by introducing the motivational assumption of "intergenerational care" 55 as operating on the deliberating parties, which reflects our natural tendency to care for the well-being of our immediate descendents. Pursuant to this motivational assumption, Rawls posits that each person deliberating in the original position cares about the well-being of some of those in the next generation: "The parties are regarded as representing family lines . . . with ties of sentiment between successive generations." 56 Thus, "for each party in the original position, we assume that their goodwill stretches over at least two generations." 57 This attempt to set up the conditions of deliberation so as to generate obligations of intergenerational savings has been met with substantial criticism. Bruce Ackerman, for one, contends that Rawls' motivational assumption of "intergenerational care" is inconsistent with the predominant motivational assumptions operating in the original

\footnotetext{
${ }^{54} I d$.

${ }^{55} \mathrm{Id}$. at 128 . Other theorists writing on the subject of intergenerational justice have made similar assumptions. See, e.g., Daniel A. Farber and Paul A. Hemmersbaugh, The Shadow of the Future: Discount Rates, Later Generations, and the Environment, 46 VAND. L. REV. 267, 294 (1993) (In working out an intergenerational savings principle with respect to public goods, "the optimum social decision requires the current generation as a whole to sacrifice the collective consumption needed to provide the desired level of public goods in the future. ... [T] he objective remains to approximate the level of sacrifice that each family would undertake willingly, in the absence of a free ride, to provide the benefits of public goods to their descendents alone. The aggregate of those individual sacrifices would provide the necessary collective sacrifice required of the current generation."). Richard Epstein also assumes a genetic predisposition to care for the well-being of one's descendents. Richard Epstein, Justice Across the Generations, 67 TEX. L. REV. 1465, 1467 (1989).

${ }^{56}$ Rawls, supra note 11, at 292.

${ }^{57}$ See also id. at 288 (In deliberating on a just savings principle, "it is assumed that a generation cares for its immediate descendents, as fathers say care for their sons.").
} 
position of the absence of intragenerational care. ${ }^{58}$ Recall that Rawls posits that the parties deliberating in the original position are mutually disinterested and are not concerned to advance anyone else's well-being but their own, ${ }^{59}$ an assumption that appears inconsistent with the motivational assumption of intergenerational care. In response to this and other criticisms of his introduction of the motivational assumption of intergenerational care as a vehicle for generating intergenerational obligations, ${ }^{60}$ Rawls subsequently modified his formulation of the conditions of the original position to remove its dependence upon this motivational assumption. In his revised formulation of the conditions in the original position in Political Liberalism, ${ }^{61}$ Rawls posits that the deliberating parties are required "to agree to a savings principle subject to the further condition that they must want all previous generations to have followed it. Thus the correct [savings] principle is that which the members of any generation (and so all generations) would adopt as the one their generation is to follow and as the principle

\footnotetext{
${ }^{58}$ See Bruce Ackerman, Social Justice in the Liberal State 225 (1980). Ackerman contends that "this altruistic psychology attributed to the contractors considering intergenerational concerns starkly contrasts with the self-interested psychology of contractors confronting intragenerational conflicts." Id. at 224-25.

${ }^{59}$ See Rawls, supra note 11, at 139.

${ }^{60}$ Other commentators have advanced criticisms of Rawls' introduction of the motivational assumption of intergenerational care into the circumstances of the original position. Jane English contends that if Rawls wishes to structure the deliberation in the original position so as to render the generation to which one belongs irrelevant, Rawls should abandon his construction that all parties in the original position are contemporaries and should imagine instead a meeting at which all generations are represented, with the veil of ignorance concealing from them the (morally irrelevant) information of which generation they belong to. Jane English, Justice Between Generations, 31 PHILOSOPHICAL STUDIES 91, 99 (1977). Rawls, however, rejects this formulation because it is inconsistent with his present time of entry interpretation, as discussed in text accompanying notes 39-40. Furthermore, English contends that even if we assume that the deliberating parties are motivated by intergenerational care as described by Rawls - with at least one person in the present generation caring about the well-being of at least one person in the next generation - this formulation can only generate short-term, not long-term, savings. English, supra, at 99.

${ }^{61}$ Rawls, supra note 28, at 274.
} 
they would want preceding generations to have followed (and later generations to follow), no matter how far back (or forward) in time.,62

Although the details of Rawls' motivational assumptions operating upon the parties deliberating regarding intergenerational justice and intergenerational savings have undergone some revisions, the general outlines of such assumptions are straightforward. In arriving at a just savings principle,

[T] he ethical problem facing the deliberating parties is that of agreeing on a path over time which treats all generations justly during the whole course of society's history. . .. No generation has stronger claims than any other. In attempting to estimate the fair rate of savings, the persons in the original position [must consider] what is reasonable for members of adjacent generations to expect of one another at each level of advance. They [must attempt to] piece together a just savings schedule by balancing how much at each stage they would be willing to save for their immediate descendants against what they would feel entitled to claim of their immediate predecessors ... [until they] arrive at an estimate that seems fair from both sides. ${ }^{63}$

Since no one [in the original position] knows to which generation he belongs, the question [of how to craft a just savings principle] is viewed from the standpoint of each [generation] and a fair accommodation is expected by the principle adopted. All generations are virtually represented in the original position. ${ }^{64}$

[In formulating a just savings principle,] the persons in the original position are to ask themselves how much they would be willing to save at each stage of advance on the assumption that all other generations are to save at the same rates. That is, they are to consider their willingness to save at any given phase of civilization with the understanding that the rates they propose are to regulate the whole span of accumulation [across the span of historical time]. . . [T] hey must choose a just savings principle that assigns an appropriate rate of accumulation to each level of advance. ${ }^{65}$

This process of accumulation, once it is begun and carried through, will then redound to the benefit of all subsequent generations. ${ }^{66}$

${ }^{62} \mathrm{Id}$.

${ }^{63}$ Rawls, supra note 11 , at 289.

${ }^{64} \mathrm{Id}$. at 288.

${ }^{65} \mathrm{Id}$. at 287.

${ }^{66} \mathrm{Id}$. at $286,289-90$. 
In sum, Rawls posits that each generation, regulated by the principle of intergenerational justice that would be chosen in the original position, is to pass along to the next generation a certain amount of savings for the benefit of society as a whole. Such savings can be conceptualized as being made "in return for what is received from previous generations that enables the later [generations] to enjoy a better life in a more just society. ${ }^{67}$ Accordingly, "savings is achieved by accepting as a political judgment those policies designed to improve the standard of life of later generations of the least advantaged, thereby abstaining from the immediate gains that are available." ${ }^{68}$ Acting in accordance with a just savings principle, "the present generation cannot do as it pleases, but is bound by the principles that would be chosen in the original position to define justice between persons at different moments of time." ${ }^{69}$

Under Rawls' formulation of just savings for future generations, the subject of such savings is not limited to financial wealth. Rather, Rawls explicitly extends the just savings principle to savings in terms of intellectual, educational, and cultural "capital.,"70 Regulated by Rawls' principle of intergenerational savings, members of earlier generations are not only required to contribute their fair share to the material riches of society; they must also contribute to the cultural advances that have been made by society at each stage of advance. ${ }^{71}$ In Rawls' words:

The process of accumulation, once it is begun and carried through, is to the good of all subsequent generations. Each passes on to the next a fair equivalent in real capital as defined by the just savings principle.... [C]apital is not only factories

${ }^{67} \mathrm{Id}$. at 288 .

${ }^{68} \mathrm{Id}$. at $292-93$.

${ }^{69} I d$. at 293.

${ }^{70} \mathrm{Id}$. at 288 .

${ }^{71}$ The savings required of each generation is to encompass "investment in learning and education" and obligates each generation to "rais[e] the standard of civilization and culture." Id. at 286 . 
and machines ... but also the knowledge and culture . . . that make possible just institutions and the fair value of liberty."72

Thus, Rawls claims that the just savings principle requires each generation to pass on to the next generation the level of culture and learning achieved by society up to that point.

After setting forth the conditions operating upon the contracting parties in deliberating upon a just savings principle and the subject of such savings, Rawls provides a broad outline of the savings principle that would be chosen in the original position. While claiming that it is not possible to define with any precision the rate of just savings, ${ }^{73}$ he contends that the proper just savings principle would obligate each generation not only to preserve the gains in culture and civilization achieved by previous generations, but further to augment ${ }^{74}$ and contribute their fair share to the wealth of society, above and beyond the contributions that have been made by previous generations. ${ }^{75}$ Regulated by a principle of intergenerational justice, persons within each

${ }^{72} I d$. at 288 .

${ }^{73} \mathrm{Id}$. at 286

${ }^{74} I d$. at 293.

${ }^{75}$ Rawls' claim that the proper intergenerational savings principle requires each generation not merely to preserve but to augment the gains in culture and civilization has been criticized by theorists such as Bruce Ackerman. In his treatise Social Justice and the Liberal State, Bruce Ackerman contends that Rawls has not adequately justified his claim that parties deliberating behind the veil would choose a savings principle that imposed the obligation on each generation not merely to preserve but to augment the material and cultural wealth of society. Ackerman argues that, on Rawls' own line of reasoning, the deliberating parties would opt not for a steadily increasing just savings program, but instead for an intergenerational trusteeship:

If anything if fundamental to A Theory of Justice, it is the claim that rational contractors will, when making their fundamental choices, focus exclusively upon their worst possible outcomes. In the present case, this means the contractors will be unimpressed by the fact that [Rawls'] "just savings" generates higher welfare to people lucky enough to land in the later generations. Instead, they will concentrate upon the sacrifices "just savings" imposes on those who come earlier. ... One would expect Rawls to predict that the liberal principle of trusteeship would be the unanimous choice of his original contractors, for they end up worse off under "just savings" if they find themselves in the first generation after leaving the original position. 
generation are therefore charged with the duty to maintain and to further just social

institutions and to advance the material and cultural wealth of society for the benefit of successor generations. $^{76}$

Under Rawls' steadily increasing just savings principle, in terms of cultural wealth, it would not be enough for earlier generations to simply preserve for future generations the developments in the arts and sciences that were achieved by previous generations. Rather, each generation has a duty broadly to advance and take to a higher level the advancement in the arts and sciences that have been made by its predecessor generations. Each generation is charged with the duty to improve upon the standard of

The only trouble is that Rawls says just the opposite. He tells us that the contractors [acting under the motivational assumption of intergenerational care] . . . are concerned with the welfare of their entire bloodline. ... [W] hy must a responsible family head want more for his children than he gets for himself? Why is it not enough to bring the child to a level of welfare equal to that the parent himself enjoys? It is always possible to shortcircuit these questions simply by stipulating that all contractors have the psychology of the quintessential Jewish mother, but this stipulation will hardly convince parents of other temperaments.

$I d$. at 224-25. Ackerman thus claims that Rawls has not adequately justified the adoption of a just savings principle in which earlier generations are required to do more than preserve or hold in trust for future generations the material and cultural wealth of society. Instead, Ackerman contends that rather than adopting a steadily increasing savings principle, rational risk-averse contractors would adopt an intergenerational trusteeship. In Ackerman's version of the intergenerational trusteeship: "so long as each generation does not deplete the per capita share of capital available to the next, further accumulation may not be demanded in the name of trusteeship, nor can less be justified." Id. at 213, 227. See also Ronald Dworkin, Symposium on the Public Benefits of the Arts and Humanities, 9 COLUM. J. OF ART \& THE LAW 123, 156-57 ("We inherit a cultural structure, and we have some duty, out of simple justice, to leave that structure at least as rich as we found it.")

Although an important theoretical debate, the issue dividing Rawls and Ackerman whether intergenerational justice requires mere trusteeship or net accumulation of society's cultural and material capital - is not pivotal for the transition from a publicly ordered realm of creators' rights to a privately ordered realm. Rather, the more pressing issue is whether presentday creators - who have benefited from a system of limited rights and savings with respect to creative works -- can now establish a system in which savings for the benefit of future creators is no longer required at all. That is, the question becomes whether present-day creators can now assert unlimited rights in their creative works and essentially abandon even the limited Ackermanian duty to serve as trustees for society's cultural advances achieved up to this point.

${ }^{76}$ Rawls, supra note 11, at 290. 
life of later generations by furthering the level of advance of cultural and material wealth that had been achieved by previous generations. ${ }^{77}$

In sum, Rawls advances a theory of justice between generations and a just savings principle in which the generation into which one is born is and should be rendered morally irrelevant. According to such a theory, the distribution of benefits and burdens made available by cooperation in society is determined without reference to an individual's temporal priority along the timeline of society. In particular, individuals deliberating in the original position are required to choose a principle of intergenerational savings that they would want all previous generations to have followed (and later generations to follow), no matter how far backward or forward in time. Members of each generation must attempt to craft a just savings principle by balancing how much they would be willing to save for future generations against what they would feel entitled to

\footnotetext{
${ }^{77}$ Rawls claims that, at some point, further increases in the wealth of society will be counterproductive and will not serve to improve later generations' standard of life. The generations "are not bound to go on maximizing indefinitely;" id. at 289; excessive and everincreasing accumulation of material wealth can constitute a "positive hindrance" to society. Id. at 290. Thus, at a certain stage of development of society, subsequent generations are no longer required to further the wealth of society, but are only charged with the obligation of maintaining such wealth. See also id. at 298 ("The just savings principle acts as a constraint on the rate of accumulation. Each age is to do its fair share in achieving the conditions necessary for just institutions and the fair value of liberty; but beyond this more cannot be required."). It is unclear whether this same cap imposed by Rawls' on his steadily increasing savings principle applies, mutatis mutandis, with respect to the cultural wealth of society. Can it be said that at some point, advances in culture and knowledge would constitute a "hindrance" to society, and that therefore the proper interpretation of the savings principle for such later generations would only require them to preserve, but not to advance, the cultural wealth of society? Because advances in culture and learning arguably continue to improve the quality of life of a society and do not have the same capacity for distraction as does excessive accumulation of material wealth, the reasoning supporting Rawls' imposition of a cap on the steadily increasing just rate of savings in the realm of material and financial wealth does not necessarily carry over to the realm of cultural advancement. See id. at 287 ("Once just institutions are firmly established, the net accumulation required falls to zero. At this point, a society meets its duty of justice by maintaining just institutions and preserving their materialbase.") (emphasis added). Thus, although the duty imposed upon each generation to further the material wealth of society at some point of advance
} 
claim of prior generations, until they reach a principle that seems fair and reasonable from both sides to govern the span of savings across historical time. Regulated by a principle of intergenerational savings, individuals within each generation are obliged to forgo immediate gains that are available to them where necessary to preserve (and augment) for future generations a certain standard of life, measured not only in financial terms, but also in terms of society's cultural and intellectual advancement.

\section{INTERGENERATIONAL JUSTICE AND AUTHORS’ RIGHTS}

The principle of justice between generations and accompanying just savings principle articulated in Part I have important implications for the design of systems of private property in general and for the design of intellectual property rights in particular. In this Part, I contend that systems of rights in creative works should be designed, consistent with intergenerational justice obligations, to embody a commitment on the part of earlier "generations" of authors to preserve certain elements and uses of their creative works for the benefit of future generations -- even where doing so requires the present generation of creators to "abstain[] from the immediate gains that are available"78 to

them. In developing this argument, I first structure a Rawlsian initial choice situation in which authors deliberate regarding the scope of rights in creative works. In order to generate a just savings principle that is consistent with obligations of intergenerational justice, I set up the initial choice situation such that the generation to which each deliberating party belongs is obscured from him or her. Parties deliberating in this initial choice situation are then charged with the task of choosing a just savings principle that

converts to the duty to merely maintain such wealth, it is not clear whether the same can be said with respect to the cultural wealth of society. 
treats all generations of creators justly over the span of historical time.

\section{A. Obligations of Intergenerational Justice and Systems of Rights in Creative Works}

\section{Constructing the Initial Choice Situation}

In modeling an initial choice situation to generate principles governing the protection of creative works consistent with the obligations of intergenerational justice, it must first be determined what range of interests will be taken into account by the deliberating parties. The initial choice situation could be structured to take into account a wide range of interests across the entire spectrum from creators to non-creators. The non-creator end of the spectrum would encompass the interests of those who stand to benefit from access to creative works, either by the mere edification that comes from such access, or by their eventual incorporation of such works into their own creations. The problem of designing a system of protections that balances the need to incentivize creation through strong property rights against the need to encourage access by limiting such property rights is a familiar one that centers primarily around intragenerational justice concerns, which focuses on the distribution of benefits among individuals belonging roughly to the same generation. In working out an initial choice situation in which individuals deliberate on the scope of rights in creative works, I will instead focus

${ }^{78}$ Rawls, supra note 11, at 292-93. 
on the related but intergenerational inquiry of the duties and obligations imposed on earlier generations of authors to successor generations of authors. ${ }^{79}$

In this section, I consider the conflicting interests and incentives operating upon successive generations of creators, so as to explore the development of a principle of justice between authors over time. Consistent with analyzing the obligations of intergenerational justice for systems of rights in creative works, the authors deliberating in this initial situation would not know to which authorial generation they belonged, whether they were born into an earlier and less culturally advanced society, or to a later, culturally advanced stage of society. That is to say, each author deliberating on the scope of rights in creative works would not know whether, upon leaving the original position, she would be creating within the cultural context of the Nineteenth or the Twenty-First Century, for example. She would not know who had written before her, what ideas had previously been embodied in works of authorship, or to what extent the process of creating her works of authorship would be dependent upon incorporating elements of works that came before her.

The authors deliberating in the original position would be charged with developing a system of rights in creative works that would be fair and reasonable to authors regardless of which creative generation across the span of historical time they turned out to belong to. The savings principle that would be chosen in this initial situation with respect to creative works would be the one that members of any authorial generation (and so all authorial generations) would adopt as the one their generation is to

\footnotetext{
${ }^{79}$ This project is more relevant to the task of justifying to present-day authors limitations on their rights. That is to say, if the interests represented in the initial choice situation encompass only the interests of authors, and if nonetheless the principle emerging out of the deliberations imposes
} 
follow and as the principle they would want all previous generations to have followed and future generations to follow, no matter how far backward or forward in time. In selecting this savings principle, the deliberating parties would consider what is fair and reasonable for adjacent generations of creators to expect from one another, and would select a just savings principle that assigns an appropriate rate of savings to each level of advance over time. Deliberating authors would consider, for example, what sort of savings it would be reasonable for them to expect on the part of authors who precede them whose works they will likely build upon in creating their own works. Concomitantly, deliberating authors would evaluate such a savings principle in light of the sacrifices it would impose upon them (in terms of forgone profits) by requiring them to save for the benefit of the immediately succeeding authorial generation.

\section{The Savings of Works of Intellectual Property}

Throughout my analysis, I have implicitly assumed that some measure of "savings" on the part of predecessor authors is required to protect the interests of future authors, and have therefore suggested that authors deliberating in an initial choice situation regarding the scope of property rights in creative works would opt for some form of "savings" with respect to such works. But this first claim, and the assumptions it embodies about the nature of the creative process, calls for closer scrutiny. What precisely is meant by the savings of creative works for the benefit of future creators? If I write a novel or a song or a software program, in what sense must such works, or elements of such works, be preserved for the benefit of future generations of creators? The subject of our inquiry is works of intellectual property, which, unlike tangible

limitations on authors' rights, then the justification for such limitations would be more appealing to present-day authors. 
property, can be enjoyed and consumed by many without diminishment, so what sense does it make to speak of the need for savings with respect to such works? It is one thing to require non-renewable natural resources like oil and gas, or intangible resources like financial capital, to be saved for the benefit of future generations. But for works of intellectual property, like novels and songs and software, which can be consumed by many without diminishment, why must certain elements or uses of them be preserved for the benefit of future generations?

The answer inheres in the recognition that even though works of intellectual property are non-rivalrous as regards their consumption, they are nonetheless excludable. That is to say, by virtue of one's positive intellectual property rights, an author can exclude others from making use of or incorporating elements of her work absent authorization. If authors can exclude others from making use of their works without their permission, such a right to exclude, if construed too broadly, will impinge upon the ability of future authors to create - at least if and to the extent that the nature of the creative process entails building upon elements of pre-existing works. Put simply, if I write the first blues song, and the state grants me a property right in that song, then depending upon the extent of that property right, I may be able to prohibit others from singing their own blues. If I write the first opera or play about starving artists struggling to make ends meet, then depending upon the extent of that property right, I may be able to prohibit others from writing their own version of the same. ${ }^{80}$ If I write the first database spreadsheet program, then depending upon the extent of my property rights in

\footnotetext{
${ }^{80}$ To use a well-known example, if the copyright owner of the opera La Boheme exercised exclusive rights regarding the portrayal of the opera's underlying ideas, then the owner could prevent the musical Rent from being made.
} 
that program, I may be able to prohibit others from writing an improved and competing spreadsheet program. $^{81}$

Yet, the scope of property rights in creative works is only problematic from the standpoint of intergenerational justice between authors if the creative process is conceptualized as one that necessarily entails the incorporation of elements of preexisting creative works. If and to the extent that the creative process is conceptualized as one that necessarily entails building upon elements of pre-existing creative works - or what I will call the "recombinative conception" of the creative process - then some measure of savings of creative works is necessary for the creative process to flourish in the long run. If and to the extent that the creative process is conceptualized as one that involves truly and utterly original creation - or what I will call the "ex nihilo" conception of the creative process ${ }^{82}$ - then savings of creative works would not be necessary for the creative process to flourish in the long run. Because the adoption of one over the other competing conception of the creative process is a highly relevant input to the parties' deliberations in the initial choice situation regarding the selection of a just savings principle for creative works, it will be worthwhile to explore these contrasting conceptions of the creative process in greater detail.

\section{Conceptions of the Creative Process}

Within the "ex nihilo" conception of the creative process, creators are conceptualized as creating their works out of thin air or out of nothing, ${ }^{83}$ and creators

\footnotetext{
${ }^{81}$ See, e.g., Lotus v. Borland, 49 F.3d 807 ( $1^{\text {st }}$ Cir. 1995), aff'd by an equally divided S.Ct., 513 U.S. 233 (1996).

${ }^{82}$ See, e.g. , JAMES Boyle, Shamans, SofTware, AND SPleEns 156 (1996).

${ }^{83}$ See, e.g., Paul Goldstein, Copyright, 38 J. OF THE COPYRIGHT SOCIETY OF THE U.S.A. 109, 110 (1991) (copyright is about "sustaining the conditions of creativity that enable an individual to
} 
therefore have no inherent need to rely upon or make use of elements of pre-existing creative works. ${ }^{84}$ In the words of philosopher James Child, an exponent of the ex nihilo conception, the process of creating intellectual property is one in which ideas are "thought of and, thus, created (or discovered) and appropriated ex nihilo, merely by hard (and creative) thought.... [The underlying components of intellectual property are] created out of nothing but mental labor. [The creator doesn't] even need raw materials . . .."85 Child contends further that because the stuff of intellectual property (unlike the stuff of real property) is inexhaustible and because the process of creation is one in which creators create ex nihilo, limitations imposed on intellectual property in order to preserve the raw materials of the creative process for other creators are unwarranted. Taking ideas as one example of the underlying components of intellectual property, Child contends that ... [I]deas are not like real property . . . , just because (as we have seen) there is a source of an infinite (or indefinitely large) number of new ideas that can be thought of and, thus, created (or discovered) and appropriated ex nihilo, merely by hard (and creative) thought. . . . [When I privatize an idea], the number available to you is not thereby decreased. ... [Y]ou are not deprived, so long as you remain able and willing to exert mental labor.... As it is with patents, so it is with copyrights. . . All of these kinds of property share the characteristic that, while I can exclude you from the use of mine, there is not thereby a smaller amount upon which you can draw to use or own. ${ }^{86}$

craft out of thin air an Appalachian Spring, a Sun Also Rises, a Citizen Kane.”), quoted in Boyle, supra note 82, at 156.

${ }^{84}$ See Boyle, supra note 82, at 56-57 (comparing conception of novelist who "crafts out of thin air," who "does not need a rich and fertile public domain on which to draw," and conception of artistry in which development is based on existing material, in which "poetry can be only be made out of other poems, novels out of other novels.")

${ }^{85}$ See James W. Child, The Moral Foundations of Intangible Property, 73 THE MonIST 578 (1990), reprinted in INTELLECTUAL PROPERTY, MORAL, LEGAL, AND INTERNATIONAL DiMENSIONS 68-69 (Adam D. Moore, ed. 1997). Furthermore, Child argues that (to the extent that creation requires something more than nothing) the components of the creative process are 
According to the ex nihilo conception of the creative process, creators create not so much by building upon pre-existing elements of others' works or by making transformative uses of pre-existing works, but by exerting mental labor to create ex nihilo. On this conception of the creative process, even though intellectual property is excludable, unlimited rights in intellectual property present no difficulties from the perspective of intergenerational justice because broad intellectual property rights for earlier authors do not impinge upon the rights of subsequent authors - who can create by exerting hard and creative thought and who can generate the relevant raw materials of the creative process ex nihilo. If and to the extent that the parties deliberating in the initial choice situation were to take as their starting place an ex nihilo conception of the creative process, in which the act of creation does not necessarily involve the incorporation of elements of pre-existing works, then limitations on authors' rights in creative works would not necessarily be warranted on intergenerational justice grounds.

In contrast, under the recombinative conception, the creative process is conceptualized as one in which creators create through a process by which they are inspired by, build upon, and recast elements of preexisting works of authorship, and make transformative and productive uses of such pre-existing works. As Jessica Litman, an exponent of the recombinative conception of the creative process, puts it:

[T] he very act of authorship in any medium is more akin to translation and recombination than it is to creating Aphrodite from the foam of the sea. Composers recombine sounds they have heard before, playwrights base their characters on bits and pieces drawn from real human beings and other playwrights' characters; novelists draw their plots from lives and other plots within their experience; software writers use the logic they find in other software; ... cinematographers, actors, choreographers, architects, and sculptors all engage

practically infinite in number, such that my exclusive ownership of a component of the creative process would not in any way impair your ability to create. $I d$.

${ }^{86}$ See Child, supra note 85, at 68-69. 
in the process of adapting, transforming, and recombining what is already 'out there' in some other form. . This . . is the essence of authorship. ${ }^{87}$

Wendy Gordon, also an exponent of the recombinative conception of the creative

process, contends that recombination is the essence of the technological as well as the

artistic process of creation and intellectual advancement:

New creators inevitably and usefully build on predecessors. In her invention of techniques, discoveries, ideas, or themes, the new creator speaks out of a history, and the very value of her contribution will depend upon her advancing upon what has come before. The inventor of the automobile builds on one predecessor's invention of metal-smelting processes, another predecessor's invention of gears, another predecessor's invention of the wheel, and ultimately on the efforts of some Promethean cave-dweller who, in discovering how to make fire, laid the groundwork for the internal combustion engine. The pattern is not limited to technological culture. Artists learn from predecessors the laws of perspective, the uses of oils, acrylics, and watercolors, and the very traditions that give meaning to their productions. As for music, it is often argued that there is a limited vocabulary available for musical composition, and that composers will inevitably and necessarily work in a received tradition, as well as re-use prior themes. Communication depends on a common language and common experience. ${ }^{88}$

Adoption of the recombinative conception of the creative process in turn requires that certain components of pre-existing creative works be preserved unowned for the benefit of future prospective authors so that they can build upon such components in creating their own works. In the oft-quoted words of Zechariah Chafee:

The world goes ahead because each of us builds on the work of our predecessors. A dwarf standing on the shoulders of a giant can see farther than the giant

\footnotetext{
${ }^{87}$ Jessica Litman, The Public Domain, 39 EMORY L. J. 965, 965-66 (1990). See also Wendy Gordon, A Property Right in Self-Expression: Equality and Individualism in the Natural Law of Intellectual Property, 102 YALE L.J. 1533, 1556 (1993).

${ }^{88}$ Gordon, supra note 87, at 1556. Further examples of theorists who argue in favor of or who presume a recombinative conception of the creative process are manifold. See, e.g., RICHARD A. POSNER, LAW AND LITERATURE 403 (1988) ("The literary imagination . . . is not a volcano of pure inspiration but a weaving of the author's experience of life into an existing literary tradition."). See also Dworkin, supra note 75, at 156 ("We must have a tradition of innovation and we must have particular forms of art sufficiently open-ended and amenable to interpretation so that continuity can be preserved through innovation ....").
} 
himself. Progress would be stifled if the author had a complete monopoly on everything [in his work for the entire copyright term or for an unlimited term]. Some use of its contents must be permitted in connection with the independent creation of other authors. The very policy which leads the law to encourage his creativeness also justifies facilitating the creativeness of others. ${ }^{89}$

In short, the adoption of one conception of the creative process over the other has significant implications for structuring a system of rights and privileges in creative works. If and to the extent that the parties deliberating in the initial choice situation were to adopt an ex nihilo conception of the creative process and conceptualize the creative process as one in which authors create out of nothing, then it matters not from the standpoint of intergenerational justice whether any limitations are imposed upon authors' rights in their works of authorship or whether any savings of components or uses of such works is required. If and to the extent that the deliberating parties were to adopt a recombinative conception of the creative process, then the creative process is conceptualized as one in which authors necessarily create by building upon components of pre-existing creative works, and certain elements and uses of creative works must be preserved for the benefit of future authors through the imposition of limitations on authors' rights.

The issue of which conception more closely reflects the actual process of creation is a complex and to some extent a circular one. It is certainly true that much of Western art, literature, and science has benefited greatly from a culture in which borrowing and "standing upon the shoulders" of one's predecessors has been permitted and

${ }^{89}$ Zechariah Chafee, Jr., Reflections on the Law of Copyright, 45 CoLUM. L. REV. 503, 533 (1945). See also Benjamin KaPlan, An UnHURried View of Copyright 2 (1967) ("Progress, if it is not entirely an illusion, depends upon a generous indulgence of copying"). 
encouraged. ${ }^{90}$ Many at the forefront of the technological revolution contend that their successes have resulted from building upon the works of their predecessors. ${ }^{91}$ Yet we could certainly conceive of creative cultures in which borrowing from others' works is discouraged or outright prohibited, or in which creation was conceptualized as occurring - and therefore encouraged to occur - ex nihilo.

Adopting a Rawlsian construction of the initial choice situation, we can assume that the deliberating parties are at least to some extent risk averse and would therefore choose to minimize their worst possible outcomes upon leaving the original position. ${ }^{92}$ Accordingly, the deliberating parties would consider and weigh the possible outcomes of the decision to save versus the decision not to save under circumstances in which they turned out to be recombinative creators compared to circumstances in which they turned out to be ex nihilo creators. In particular, they would evaluate two competing outcomes: (1) the worst case outcome if, upon leaving the original position, they turned out to be ex nihilo creators; and (2) the worst case outcome if, upon leaving the original position, they turned out to be recombinative creators who therefore needed to build upon the preexisting works of earlier creators. Uncertain about whether, upon exiting the initial choice situation, they would become ex nihilo creators or recombinative creators, and facing the decision of whether to save elements and uses of their creative works for the benefit of subsequent creators, the parties would adopt the alternative the worst outcome

\footnotetext{
${ }^{90}$ To take an especially well-known example, Shakespeare is considered to be among the greatest literary borrowers of all times, and not coincidentally, also among the most creative. See Posner, supra note 88 , at 403, 396. My aim is not to answer the question of which conception of the creative process most accurately reflects the creative process, but rather to elucidate the differences between the two conceptions and to explore the implications of the adoption of one conception over the other for a system of rights and limitations in creative works.

${ }^{91}$ See Boyle, supra note 82, at 165 (describing opposition of several prominent computer experts to broad intellectual property rights in software).
} 
of which is superior to the worst outcome of the others (which Rawls denominates the "maximin" principle). ${ }^{93}$ Consistent with the maximin principle, the deliberating parties would select some type of savings principle, because the worst possible outcome of the decision to adopt a savings principle with respect to creative works is superior to the worst possible outcome of the decision not to save - in which creation is impossible or severely impaired if upon leaving the original position an author turns out to need to make use of pre-existing creative works in creating her own works.

Having decided to minimize their worst possible outcomes upon leaving the initial choice situation and to thereby adopt a savings principle of some sort, the deliberating parties would then need to determine how broad or narrow a savings principle to adopt with respect to creative works. In doing so, they would need to agree on a path over time that treats all generations of creators justly during the course of society's creative history. ${ }^{94}$ In particular, they would be charged with choosing a principle of savings that they would want all previous authorial generations to have followed, and would want all future authorial generations to follow, no matter how far backward or forward in time. ${ }^{95}$ Given these constraints on their decision-making, the deliberating parties would not credit an argument for extensive and unlimited creative rights representing solely the interests of authors who had already created their work and who sought to maximize their share of wealth accruing from such creations, because the deliberating parties would be required to agree on a savings principle in cultural materials

\footnotetext{
${ }^{92}$ See Rawls, supra note 11, at 152-53.

${ }^{93} \mathrm{Id}$. at $152-53$.

${ }^{94} I d$. at 291.

${ }^{95}$ See Rawls, supra note 28, at 274.
} 
that they would want all previous generations to have followed. ${ }^{96}$ If previous generations of authors had secured maximal rights for their works, then pursuant to the recombinative conception of the creative process, present-day authors would have been unable to create their own works. Thus, the deliberating parties, taking into account the interests of all creative generations, would agree to limits on the rights of all authors in order to preserve the raw materials of the creative process for all authors, regardless of when they arrived on the timeline of society.

\section{Translating Mandated Savings into Specific Limitations on Authors' Rights}

Having concluded that authors behind the veil of ignorance would opt for some system of mandated savings in creative works, I next take up the consideration of how such "savings" of creative works would translate into limitations to be imposed on authors' rights. In this section, I contend that parties deliberating in an initial choice situation who were concerned to protect the interests of all generations of creators would include: (1) limitations on the scope of rights in creative works, such that the fundamental raw materials for subsequent authors' process of creation would remain available to them; (2) limitations on authors' right to control transformative uses of their works; (3) limitations on authors' right to control critical assessments of their works; and, possibly (4) durational limitations on authors' rights in their works. My analysis of the interests and incentives operating upon authors in a Rawlsian initial choice situation supports limitations on authors' rights that partially overlap with the limitations imposed on

${ }^{96} I d$. 
copyright rights, as discussed in Part III. Yet, my analysis diverges from copyright law's justifications for limiting rights in several ways. First, my analysis is rights-based focusing on the right of authors across historical time to create -- whereas copyright law's is predominantly utilitarian. Second, unlike mainstream copyright theory, my analysis does not take into account the role of transactions costs in justifying limitations on authors' rights. ${ }^{97}$ Because my analysis aims to justify limitations on creators' rights in the digital age -- where transactions costs are supposedly diminishing ${ }^{98}$-- I focus on justifications other than transactions costs for limiting authors' rights. ${ }^{99}$

\section{a. Limitations on the Scope of Rights in Creative Works}

Not knowing which creative generation along the timeline of society they would turn out to belong to upon leaving the original position, authors deliberating in the original position would choose to preserve for later generations of authors access to the raw materials and fundamentally reusable elements of the creative process. Thus, for example, deliberating authors would seek to preserve for subsequent authorial generations reusable creative elements like ideas and ideational elements - including stock characters, situations, plot lines, etc. ${ }^{100}$-- that could be reformulated and

\footnotetext{
${ }^{97}$ See, e.g., Wendy Gordon, Fair Use as Market Failure, 82 CoLuM . L. REV. 1600 (1982) (contending that the fair use doctrine in copyright law can be explained as a response to market breakdown between earlier authors/would-be licensors and subsequent authors/would-be licensees).

${ }^{98}$ See, e.g., Robert P. Merges, The End of Friction? Property Rights and Contract in the "Newtonian" World of On-Line Commerce, 2 BERK. TECH. L.J. 115 (1997); Richard Alan Horning, Has Hal Signed A Contract: The Statute of Frauds in Cyberspace, 12 SANTA ClarA COMPUTER \& HigH TECH L.J. 253, 256 (1996).

${ }^{99}$ Cf. William M. Landes \& Richard A. Posner, An Economic Analysis of Copyright Law, $18 \mathrm{~J}$. LEGAL STUDIES 325 (1989) (arguing that authors, from an ex ante position, would opt for certain types of limitations on their rights because of the high transactions costs associated with consensual bargains in certain circumstances).

${ }^{100}$ Although, for simplicity, I rely primarily on literary examples, the importance of preserving ideas embodied in creative works applies as well to technological works of authorship, such as software programs, which contain such ideational elements as algorithms and basic procedures
} 
reincorporated into creative works by subsequent authors. Even if it could truly be said that such ideas and ideational elements were initially created by any one author, the deliberating parties, applying a principle of intergenerational justice, would opt to save such components for the benefit of future authors by excluding them from the scope of creators' rights in their works. As Richard Posner contends with respect to the ideational elements embodied in literary works:

[I]n order to pass the test of time ... a [literary] work must be relatively impervious to cultural change. It must therefore deal ... with the recurrent problems of the human condition - with the commonplaces of life, with stock situations, stock characters, stock narratives. . . [As] ideas in literature ... comprise a quite limited stock of situations, narratives, and character types, to recognize property rights in them would ... deplete the stock of literary raw material available for later writers without fee. ${ }^{101}$

Of course, forging the line between non-privatizable ideational elements and other, privatizable elements of creative works will be an intricate task. In drawing the relevant lines, parties should generally be guided by the recombinative conception of the creative process, and should ensure that rights in creative works are designed such that later authors have access to certain fundamental components of the creative process.

\section{b. Limitations Facilitating Subsequent Transformative Uses of Creative Works}

In translating a just savings principle into limitations on authors' rights in their creative works, authors deliberating in an initial choice situation would also opt to preserve for later authors the right to make transformative uses of prior creative works. Subsequent authors would be granted the right to incorporate limited portions of all elements (not just the ideational elements) of prior works if and to the extent that these

which other software developers arguably need to recombine and recast in creating their own works. See, e.g., Whelan v. Jaslow, 797 F.2d 1222 (3d Cir. 1986); Computer Associates v. Altai, 982 F.2d 693 (2d Cir. 1992). 
subsequent works built upon and transformed such elements of the earlier works. It would be insufficient, for example, to grant creators of biographies, histories, and journalistic works the right to merely reformulate the ideas contained within pre-existing works. ${ }^{102}$ Such creators of essentially referential works would likely need to be able to incorporate direct quotations from prior works in order to create their own works. ${ }^{103}$ In accurately painting the history of a particular period, the historian may need to quote or copy directly from prior creative works in creating her own transformative work. Thus, it would not suffice to design a savings principle that merely entitled authors to incorporate ideational elements form pre-existing works. In order to ensure that later authors of referential works are able to exercise their right to create, authors deliberating in the initial choice situation would opt to impose limitations on authors' rights to exercise exclusive control over subsequent transformative uses of their own works. ${ }^{104}$

\footnotetext{
${ }^{101}$ Posner, supra note 88, at 393-94 (emphasis added).

${ }^{102}$ See, e.g., Pierre Leval, Toward a Fair Use Standard, 103 HARV. L. REV. 1105, 1111-16 (1990).

${ }^{103}$ For example, in the case of New Era Publications Int'l v. Henry Holt, the author of a biography of L. Ron Hubbard, founder of the Church of Scientology, sought to establish that Hubbard was dishonest, cruel, and bigoted (among other things). In order to do so, the biographer claimed that she needed to make use of actual quotations of Hubbard (taken from copyrighted works) in writing her biography. See New Era Publications Int'l v. Henry Holt, 695 F. Supp. 1493 (S.D.N.Y. 1988), aff'd on other grounds, 873 F.2d 576 (2d Cir. 1989).

${ }^{104}$ This category of transformative, productive uses may also extend to uses of pre-existing works for purposes such as research or education, the transformative or productive character of which is more indirect or diffuse than in the above examples. Thus, even if, for example, a teacher's copying of a portion of a creative work appears at first blush to be merely reproductive, not productive, and even if her students do not then immediately make a transformative use of the copied work, nevertheless such educational use may be transformative in the long run, by serving as an input to the creative endeavors of students at some point in the future. Whether such indirectly transformative educational and research uses would be permitted as fair and free uses may depend on the level of wealth achieved at any particular stage of society. See Rawls, supra note 11 , at 290 . In a sufficiently wealthy society, subsidies for educational fair use, for example, at the expense of authors, may no longer be warranted, whereas in a less well off society, such subsidies might be warranted. Cf. Merges, supra note 98, at 134-35 (arguing that in the cyberspace realm, copyright law's fair use doctrine should be justified on the explicitly
} 


\section{c. Limitations Facilitating Subsequent Evaluations of Creative Works}

Thirdly, authors deliberating in the initial choice situation would opt to limit all authors' rights so as to permit evaluative uses to be made of authors' works, even where such evaluative uses have the effect of harming the market for a particular author's work. Although this category of uses might be subsumed within the above category of transformative uses (for example, in the case of parodies), it is worth considering such uses separately because of the unique barriers such uses impose to consensual bargaining between earlier authors and subsequent authors. While it is conceivable that earlier authors would consent to or license for a fee certain transformative uses of their works, it is unlikely that they would voluntarily permit critical, evaluative uses to be made of their works. In choosing between a rule that prohibited evaluative, critical uses and a rule that privileged such uses, the deliberating parties would consider the benefits that evaluative uses provide to authors as a class, including by enabling them to rely upon such unbiased evaluations in determining which works to build upon in creating their own works. Recognizing that such evaluative uses tend to benefit authors as a class because they encourage consumer confidence in works of authorship, the deliberating parties would permit such uses and would limit all authors' rights accordingly.

\section{d. Durational Limits on Rights in Creative Works}

It will often be difficult to draw the line between those elements and uses of works that should fall within an author's exclusive rights pursuant to the above intergenerational justice analysis, and those that should fall outside the scope of an author's exclusive rights. To account for the possibility that such lines may be drawn

redistributive grounds of granting subsidies to particular classes of creators, instead of on the conventional grounds of overcoming barriers to the formation of markets). 
imperfectly and in a manner insufficiently protective of future authors' creative rights, deliberating parties may opt to impose bright line durational limits on authors' rights in their works as a type of fail-safe measure. Such durational limitations would ensure that, at some point, all elements and subsequent uses of creative works would be freely available for use by subsequent authors. If, for example, the plot lines of star-crossed lovers or desperate starving artists were somehow (erroneously) determined to fall within an authors' exclusive rights so that the first author embodying such plot lines could exercise exclusive rights with respect to them, then the imposition of the fail-safe of durational limitations on such rights would ensure that future authors at some point would be permitted to incorporate such ideational elements into their own works.

Yet even if it were known that the relevant lines demarcating authors' exclusive rights could be drawn perfectly in every case, the deliberating parties might still opt to impose durational limits on creative rights, on the grounds that certain prior works may in their entirety become so integral to the creative vocabulary that subsequent creators should be permitted to make free use of them in their entirety in creating their own works. The authors deliberating in the initial choice situation might opt to protect subsequent authors' right to make extensive use of prior creative works that have become so deeply embedded within our cultural framework as to become essential to other authors' ability to create. Deliberating parties might therefore choose to structure the system of authors' rights and limitations in such a way as to allow authors after a period of time to freely and fully incorporate and build upon works like Homer's Odyssey, ${ }^{105}$

${ }^{105}$ Twentieth Century Irish author James Joyce built extensively upon Homer's Odyssey in creating Ulysses, one of the greatest works of the past century. 
Shakespeare's Romeo and Juliet,${ }^{106}$ Mozart's Marriage of Figaro,${ }^{107}$ or Virginia Woolf's Mrs. Dalloway ${ }^{108}$ in creating their own transformative works.

In short, authors deliberating behind a veil of ignorance that obscured from them information as to which creative generation along the timeline of society they belonged would opt for limitations on authors' rights that would preserve for subsequent authors the ability to fully exercise their creative rights, including the ability to incorporate ideational elements from prior works, to make transformative and evaluative uses of prior works, and possibly, to make full and free use of all prior works after a certain period of time.

\section{B. An Economic Analysis of Just Savings of Creative Works}

The economic analysis of copyright law set forth by William Landes and Richard Posner, ${ }^{109}$ while emanating out of a utilitarian tradition quite different from the Rawlsian rights-based framework pursued above,${ }^{110}$ provides some helpful guidance in analyzing the contours of the savings principle that would be chosen by authors behind the veil of ignorance. Consistent with Rawls' principal goal in A Theory of Justice of advancing justice as fairness as an alternative to utilitarian theories of distributive justice, Rawls contends that the parties deliberating in the original position would reject a utilitarian principle for guiding their decisions regarding the distribution of the benefits and burdens

\footnotetext{
${ }^{106}$ Many authors have built upon the story of Romeo and Juliet, including Arthur Laurents in his creation of West Side Story, which was set to music by Leonard Bernstein.

${ }^{107}$ Famous contemporary director/producer Peter Sellars has transformed several Mozart operas using modern sets and characterizations, including The Marriage of Figaro.

${ }^{108}$ Michael Cunningham's wonderful recent novel The Hours is closely based on Virginia Woolf's Mrs. Dalloway.

${ }^{109}$ William M. Landes \& Richard A. Posner, An Economic Analysis of Copyright Law, $18 \mathrm{~J}$. LEGAL STUDIES 325 (1989).
} 
of societal cooperation and would adopt his two principles of justice instead. ${ }^{111}$ In this section, however, I consider what flows from an initial choice situation where the parties were guided by a principle of utility in their deliberations regarding the nature and scope of rights in creative works.

In their economic analysis of copyright law, Landes and Posner explore the tensions between (1) the interests of earlier "generations" of authors - i.e., those who have already created their works -- in expanding their rights, and (2) the interests of future generations of authors - i.e., those who have not yet created their works - in limiting the rights of the authors who come before them. Landes and Posner consider the conflicting motivations and preferences at work among different generations of authors regarding the scope of rights in creative works. Assuming that the process of creation is essentially recombinative in nature, ${ }^{112}$ Landes and Posner claim that where rights in creative works are limited, subsequent authors can more cheaply and easily borrow from pre-existing works. The cost of creation for later authors is accordingly lower under a regime in which authors' rights in their creative works are limited. ${ }^{113}$ On the other hand, in a regime of unlimited, extensive property rights in creative works, in which all copying of such works is prohibited, the cost of creating new works is higher and the number of

\footnotetext{
${ }^{110}$ Note that Rawls himself explores the possible implications of the deliberating parties selecting a utilitarian principle, instead of the two principles of justice, as their foundational principle in the original position. See Rawls, supra note 11, at 161-75.

${ }^{111}$ See Rawls, supra note 11, at 161-75.

${ }^{112}$ Landes and Posner contend that "creating a new work typically involves borrowing or building upon material from a prior body of works, as well as adding original expression to it. A new work of fiction, for example, will contain the author's expressive contribution but also characters, situations, plot details, and so on, invented by previous authors." Landes \& Posner, supra note 109 , at 332 .

${ }^{113}$ Id.
} 
future works created will likely be lower. ${ }^{114}$ As Posner contends in his treatise Law and

\section{Literature,}

The more extensive copyright protection is, the more inhibited is the literary imagination. .. The works of previous writers are inputs into current work, and these inputs get more expensive the more those earlier works are protected by copyright. If every author of an epic poem had to pay royalties to Homer's heirs, then Virgil, Dante, Ariosto, Milton, Pope, Goethe, and others would have had to incur an additional expense to write their epics [and therefore may not have created such works]. ${ }^{115}$

In their economic analysis of copyright law, Landes and Posner suggest that, in designing a system of rights and limitations on rights in creative works, authors as a class would approach the question of the scope of rights in creative works from the ex ante position by taking into account two different perspectives: (1) the perspective of the present (or the "earlier") generation of authors, who have the incentive to limit the extent to which creative works can be mined as source material for other works; and (2) the perspective of subsequent authors, who wish to borrow from pre-existing works in order to create

${ }^{114}$ Id. See also Posner, supra note 88, at 391 ("Shakespeare would have had to work harder, and so might have written fewer plays, had he not been able to copy gratis from works of history and literature ....")

${ }^{115} I d$. at 403, 396. Posner's analysis is echoed by Wendy Gordon, who argues similarly that the enforcement of limitations on the creative rights of (earlier) authors is necessary to ensure that later authors will have the full and fair opportunity to create:

One cannot assume that early creators or their heirs would consent to the use of property by others to create new intellectual products if the first creators had control of these necessary prior resources. [While some owners might consent to uncompensated or reasonably compensated use,] others might refuse to sell altogether or charge more than the new creators can afford. More significantly, the cost of tracing ownership and effecting transactions could itself be prohibitive... . Thus, if perpetual property existed in all intangibles, many creators would have to choose between using someone else's property without permission, or forgoing creation of their own. . . . For new creators to flourish, they must be able to draw on an array or prior creations that are not privately owned.

Gordon, supra note 87, at 1557. 
their own works and who therefore prefer limited rights in creative works. ${ }^{116}$

Approaching the issue of the scope of rights in creative works solely from the first type of author's perspective, deliberating parties would opt for extensive property rights in creative works, while introducing the subsequent author's perspective into the analysis would counsel in favor of limited property rights in creative works. As Landes and Posner explain:

Copyright holders might therefore find it in their self-interest, ex ante, to limit copyright protection. To the extent that a later author is free to borrow material from an earlier one, the later's cost of expression is reduced; and, from an ex ante viewpoint, every author is both an earlier author from whom a later author might want to borrow material and the later author himself. In the former role, he desires maximum copyright protection for the works he creates; in the latter, he prefers minimum protection for works created earlier by others. In principle, there is a level of copyright protection that balances these two competing interests . . . ${ }^{117}$

As Landes and Posner suggest, the imposition of limitations on rights in creative works serves the goal of advancing the creative process in both the short run and the long run, ${ }^{118}$ by requiring present-day authors to forgo the profits they would earn if they enjoyed unlimited rights in their works, in the interest of subsequent authors.

\footnotetext{
${ }^{116}$ Landes \& Posner, supra note 109, at 333.

${ }^{117}$ Id. at 333. Paralleling Rawls' analysis of the incentives operating upon earlier and later generations in the original position, Landes and Posner go on to note that the first generation of authors, having no one to borrow from, would have less incentive to strike the optimal balance than later ones, and that later generations who expected to borrow less than they are borrowed from will prefer broader rights in their works than those expecting to be net borrowers. However, they note that, "ex ante . . before anyone knows whether he is likely to be a net 'debtor' or 'creditor,' authors should be able to agree on a level of copyright protection." Id. at 333 n.13.

${ }_{118}$ Cf. Frank H. Easterbrook, The Court and The Economic System, 98 HARV. L. REV. 4,26 (1984) (Observing that the Supreme Court has attempted to take an ex ante analysis of the creative process with respect to certain new technologies.)
} 
Landes and Posner's ex ante analysis of authors' interests and incentives undertaken from an economic perspective justifies imposing limitations on authors' rights, several of which coincide with the limitations justified by the above Rawlsian analysis. First, the economic analysis provides a rationale for declining to extend property rights to the ideas underlying works of authorship:

Suppose our $\mathrm{N}$ authors did not know which would be the first to come up with an idea that the other $\mathrm{N}-1$ authors would use.... Since ... the costs involved in coming up with the kind of new idea normally embodied in an expressive work usually are low relative to the costs in time and effort of expressing the idea, ... the $\mathrm{N}$ authors ... probably would agree unanimously (or nearly so) to a rule that protected expression but not ideas. ${ }^{119}$

Relying on a version of the hypothetical tripartite contract between predecessor authors, the present generation of authors, and successor authors, Landes and Posner's economic analysis provides a justification for limiting the scope of property rights in works of authorship to exclude ideas and similar ideational elements.

Similarly, Landes and Posner suggest that, ex ante, authors would agree to limitations on their rights that were necessary to ensure that subsequent authors could make transformative uses of elements of earlier works as the inputs to the subsequent authors' works. In particular, they argue, subsequent authors may need to make use of inputs from earlier works that are not properly considered ideas, but yet are part of the raw materials from which such authors would need to be able to draw. Because such transformative uses would lower the cost of expression for all authors and would therefore tend to increase the number of

${ }^{119}$ See Landes \& Posner, supra note 109, at 347-48. 
works created, such limitations would be justified under Landes and Posner's economic analysis. $^{120}$

Landes and Posner further suggest that ex ante, authors would agree to limitations on their rights where necessary to allow subsequent authors to make

critical uses of earlier works, for purposes such as book reviews and parodies. ${ }^{121}$ They contend that authors ex ante would choose to impose limitations on their exclusive rights necessary to allow for production of credible and unbiased reviews of their works, because such reviews facilitate a reliable market in creative works, which in turn redounds to the benefit of authors as a class. ${ }^{122}$ Finally, Landes and Posner contend that ex ante, authors would agree to a limited term for authors' rights in their works. In balancing the increased income attributable to longer terms of protection against the increased cost of expression for authors because of the diminished public domain, authors ex ante would opt for a limited term of rights in their works. ${ }^{123}$

In sum, although Landes and Posner's economic analysis of copyright rights grows out of a utilitarian tradition which contrasts with the rights-based Rawlsian analysis of authors' rights set forth above, both analyses support limiting authors' rights in several significant respects.

\section{Possible Objections to Requiring Intergenerational Savings of Creative Works}

In Parts I and II, I have argued that, deliberating behind a veil of ignorance, where authors did not know which creative generation they would be born into, authors

${ }^{120} \mathrm{Id}$. at $360-61$.
${ }^{121} \mathrm{Id}$. at $358-60$.
${ }^{122} \mathrm{Id}$. at $358-60$. 
would agree to certain limitations on their rights, which we can construe as requiring savings of portions of their works for the benefit of all generations of authors. In this section, I anticipate and address some objections to my analysis of the just savings required of authors. In particular, Richard Epstein, writing on the subject of intergenerational justice, intergenerational savings, and property rights, ${ }^{124}$ contends that any requirement of savings imposed on the present generation for the benefit of future generations is unnecessary and inefficient. While Landes and Posner's economic analysis justifies the imposition of limitations on creators' rights similar to those justified on an intergenerational justice analysis, Richard Epstein's economic analysis suggests that no limitations on the present generation's rights are justified in order to protect the interests of subsequent generations. Epstein apparently would reject any system of mandated intergenerational savings applied to property rights generally, ${ }^{125}$ and would rely solely on the market, and our genetic predisposition to save for our immediate descendents, to ensure sufficient savings for future generations.

In his article Justice Across the Generations, ${ }^{126}$ Epstein first contends that the preeminent contributors to the subject of justice between generations "focu[s] too much on duty and too little on practice and incentive." ${ }^{127}$ Rejecting the Rawlsian approach of looking to the state to enforce the obligations owed by earlier generations to subsequent ones, Epstein contends that:

Coercion and duty can do little specifically to insure that the next generation receives its "fair share" of human and natural resources. If we continue along in

\footnotetext{
${ }^{123} I d$. at 361-62.

${ }^{124}$ Richard Epstein, Justice Across the Generations, 67 TEX. L. REV. 1465 (1989).

${ }^{125}$ Epstein would, however, carve out several exceptions for environmental and common pool problems. Id. at 1489.

${ }^{126} I d$.

${ }^{127}$ Id. at 1466.
} 
an unreflective state to create sound institutions for the present, the problem of future generations will pretty much take care of itself, even if we do not develop some overarching policies of taxation or investment that target future generations for special consideration. . . . A classical liberal regime of limited government, low taxation, personal liberty, and private property benefits future generations more than an alternative regime that consciously enlists large government to restrain liberty and to limit the present use of property for the benefit of future generations. $^{128}$

Epstein contends that in order to safeguard the interests of future generations, we can and should rely upon the natural and genetic pre-dispositions of parents to save for the benefit of, and to otherwise act in the best interests of, their children. Historically, Epstein contends, reliance on (and non-interference with) such natural predispositions has allowed future generations to receive benefits from past generations that "far exceed the level of transfers stipulated under any of the standard theories of justice between generations." 129

Epstein, however, seems to acknowledge that this laissez-faire approach to intergenerational savings may not suffice to generate the proper amount of savings with respect to intellectual property. First, in shifting the focus of his discussion from the subject of real property to intellectual property, he explicitly acknowledges the importance of the public domain traditionally carved out by intellectual property law for the benefit of future generations of creators. ${ }^{130}$ Although he does not specifically address the desirability of a private ordering regime in which creators are able to create unlimited

\footnotetext{
${ }^{128} I d$. (emphasis added).

${ }^{129} I d$. at 1488 .

${ }^{130}$ See, e.g., id. at 1488 ("There is . . a huge body of intangibles properly regarded as part of the public domain.") (emphasis added). He also specifically recognizes the importance of limiting the term of property rights in creative works. Epstein writes that "the hard question with copyrights ... concerns their ideal duration .... The tradeoff is that longer periods of protection induce greater invention, but only at the cost of more limited use over time. The trick is to minimize the sum of the two costs. If this is done in present value terms, future generations will be well served by the regime of property rights so created." Id. at 1488.
} 
rights for themselves, he does recognize the benefits that the existing public ordering regime provides to subsequent generations of creators. ${ }^{131}$ Furthermore, his reliance upon parents' genetic predisposition to save for the benefit of their children does not apply, mutatis mutandis, to the relationships among successive "generations" of creators. That is to say, although we might be justified in relying upon Johann Sebastian Bach and Woodie Guthrie to set aside financial nest-eggs for Johann Christian and Arlo, respectively, we would be unjustified in relying solely upon these parents' genetic predispositions to set aside portions of their creative works for the benefit of future generations of creators generally. Thus, Epstein's analysis cannot justify reliance on a system of unlimited rights in creative works -- such as those increasingly made possible by technological and contractual private ordering measures -- to protect the interests of successive generations of creators.

In sum, in Parts I and II, I have argued that intergenerational justice obligations applied to systems of rights in creative works justify imposing limitations on authors' rights in creative works in order to protect the rights of all authors. Whether applying Rawlsian deontological principles or utilitarian principles of distributive justice, authors deliberating behind a veil of ignorance that obscured from them information as to which generation they belonged would opt for limited rights in creative works and for the concomitant savings of portions of creative works for the benefit of future generations of authors.

\section{LIMITATIONS HISTORICALLY IMPOSED BY COPYRIGHT LAW ON R IGHTS IN CREATIVE WORKS}

131 Id. 
Copyright law grants rights to authors in order to advance its constitutionallymandated utilitarian purpose. ${ }^{132}$ Property rights are granted to authors not in reward for their labor, but in furtherance of copyright law's utilitarian mandate of advancing the creative process for the general public good. Utilitarian considerations dictate, however, that when the rights granted to authors stand as an impediment to advancing the societal creative process, such rights must be limited in order to advance the greatest (creative) good for the greatest number. Accordingly, copyright rights are always contingent upon whether such rights continue to serve the ultimate societal good of advancing the creative process. Consistent with its utilitarian mandate, copyright law grants rights to authors in order to stimulate the creative process, but limits those rights where necessary to avoid impeding the creative process.

Although the limitations on authors' copyright rights have historically been understood to advance copyright law's utilitarian purpose, such limitations also constitute a form of mandated intergenerational savings imposed on each generation of authors for the benefit of future generations of authors. Although Congress and the courts have not explicitly adverted to principles of intergenerational justice in justifying limitations on creators' rights, such themes can be seen to inhere in the jurisprudence of copyright limitations. In myriad circumstances in which authors have sought to wield their exclusive rights in ways that would fail to preserve the raw materials of the creative process for subsequent generations of authors to build upon, copyright law has imposed significant limitations on creators' rights. Because present authors acting in their own interests do not have sufficient incentive to "save" for the benefit of future authors,

132 The Constitution empowers Congress to enact copyright and patent statutes "to promote the progress of science and the useful arts." U.S. Const., art. I, § 8, cl. 8. 
copyright law has traditionally mandated the savings of certain elements and uses of authors' creative works for the benefit of future authors. Below I explore the ways in which copyright law's limitations on authors' rights both advance the utilitarian purpose of promoting the creative process for the greater public good and enforce obligations of intergenerational justice between authors.

First, an author's copyright monopoly lasts only for a limited time, ${ }^{133}$ in accordance with the constitutional mandate of a limited copyright term. ${ }^{134}$ Thus, in contrast to real property rights, intellectual property rights in creative works are constitutionally required to be of limited duration. Second, copyright protection is only available for certain types of works and certain elements within such works. ${ }^{135}$ Finally, certain uses of works that are protected by copyright - even of the protectible elements of these works - fall outside of a copyright holder's exclusive rights and are privileged as fair uses of such works. ${ }^{136}$ Below I briefly describe each of these limitations, which have been explored elsewhere in the literature. ${ }^{137}$

\section{A. Works For Which The Copyright Term Has Expired}

An important limitation on copyright rights is the durational limit imposed by the term of copyright protection. ${ }^{138}$ In accordance with the explicit constitutional mandate in the Copyright Clause, ${ }^{139}$ property rights in works of authorship are required to be of

\footnotetext{
${ }^{133}$ See 17 U.S.C. $\$ 302$ (a).

${ }^{134}$ See text accompanying notes $139-41$.

${ }_{136}^{135}$ See text accompanying notes $142-54$.

${ }^{136}$ See text accompanying notes 155-66.

${ }^{137}$ See, e.g. , Jessica Litman, The Public Domain, 39 EMORY L. J. 965, 965-66 (1990); Wendy Gordon, Fair Use as Market Failure, 82 COLUM . L. REV. 1600 (1982).

${ }^{138}$ See 17 U.S.C. $\$ 302($ a).

${ }^{139}$ See U.S. CONST., ART. I, § 8, CL. 8. (granting Congress the power "to promote the progress of science and the useful arts, by securing for limited times to authors and inventors the exclusive right to their respective writings and discoveries.") (emphasis added).
} 
limited duration. Because of such durational limits on copyright rights, works of authorship from the Eighteenth, Nineteenth, and early Twentieth Centuries in their entireties are within the "public domain" and can be freely used by subsequent authors. Because such works are no longer protected by copyright, future authors can make any and all uses of works such as Herman Melville's Moby Dick, Charlie Chaplin's film The Tramp, or Mahler's Second Symphony. Although the term of copyright protection has expanded dramatically over the past two centuries, ${ }^{140}$ the constitutionally-required limited term of copyright protection ensures that, at some point, earlier authors' works will pass into the public domain where they can be freely and fully used by other authors and incorporated into future creative works. ${ }^{141}$

\section{B. Unprotected Elements of Copyrighted Works}

A second fundamental limitation imposed by copyright law on creators' rights encompasses those elements of otherwise copyrightable works that are excluded from the scope of an author's monopoly. In myriad court decisions throughout the past centuries, courts have expressly withheld certain elements of otherwise copyrightable works from the exclusive control of authors. These unprotectable elements include primarily facts, ${ }^{142}$ which are not original to the author and are therefore not properly included as part of a

\footnotetext{
${ }^{140}$ Over the past centuries, this limited term has been extended from two years, to 14 , to 21 , to 28 , to 56 , to life of the author plus 50 years, to its current length of life of the author plus 70 years for individual authors. See NimmER On COPYRIGHT, at 1.05[A][1]. Constitutional challenges to the recent expansion of the copyright term by twenty years have been unsuccessful. See Eldred v. Reno, _ F.3d _ (D.C. Cir. 2001).

${ }^{141}$ As Wendy Gordon contends, "if perpetual property existed in all intangibles, many creators would have to choose between using someone else's property without permission, or forgoing creation of their own. . . . For new creators to flourish, they must be able to draw on an array of prior creations that are not privately owned." Gordon, supra note 87, at 1557.

${ }^{142}$ See 17 U.S.C. § 102(b) (""In no case does copyright protection for an original work of authorship extend to any ... discovery, regardless of the form in which it is described, explained, illustrated, or embodied in a work."); Feist v. Rural Tel. Serv. Co., 499 U.S. 340 (1991).
} 
creator's rights qua creator, and ideas and ideational elements, ${ }^{143}$ which - even if ostensibly created by the author -- are deemed to fall outside the scope of the author's monopoly under the judicially crafted "idea/expression dichotomy." 144

In developing the idea/expression dichotomy, courts have attempted to draw a boundary between the underlying ideas on which a work is based and an author's particular expression of such ideas, and have held that the ideas themselves - including such ideational elements as stock characters, general themes, or plots ${ }^{145}$ contained within works - are not within the scope of the author's monopoly. Copyright law dictates that these latter components of works of authorship be dedicated to the public domain and cannot be rendered subject to the private control of any one author. ${ }^{146}$ Under the doctrine

${ }^{143}$ See 17 U.S.C. § 102(b) ("In no case does copyright protection for an original work of authorship extend to any idea, ... regardless of the form in which it is described, explained, illustrated, or embodied in a work.")

${ }^{144}$ See, e.g., Nichols v. Universal Pictures Corp., 45 F.2d 119, 121 (2d Cir. 1930); RoBERT A. GORMAN \& JANE C. GINSBURG, COPYRIGHT FOR THE NINETIES 96 (1981).

${ }^{145}$ See, e.g., Warner Bros. Pictures v. Columbia Broadcasting Sys., 216 F.2d 945 (9th Cir. 1954) ("If the character is only the chessman in the game of telling the story, he is not within the area of protection afforded by the copyright"), cert. denied, 348 U.S. 971 (1955); Nichols v. Universal Pictures Corp., 45 F.2d 119, 121 (2d Cir. 1930) (Hand, J.) ("If Twelfth Night were copyrighted, it is quite possible that a second comer might so closely imitate Sir Toby Belch or Malvolio as to infringe, but it would not be enough that for one of his characters he cast a riotous night who kept wassail to the discomfort of the household, or a vain and foppish steward who becomes amorous of his mistress. These would be no more than Shakespeare's "ideas" in the play [and not] capable of monopoly.")

${ }^{146}$ In addition to preserving the raw materials of the creative process in the public domain, the idea/expression dichotomy also advances important First Amendment values. In particular, because copyright law's idea/expression dichotomy prohibits authors from monopolizing the ideas embodied in their works, copyright law ensures that members of the public are allowed to communicate freely and build upon such ideas (so long as they do not appropriate the precise form in which the ideas were conveyed by the original author). The Supreme Court has explained that "[c]opyright's idea/expression dichotomy strikes a definitional balance between the First Amendment and the Copyright Act by permitting free communication of [uncopyrightable material such as ideas and] facts, while still protecting an author's expression." Harper \& Row Pubs ., Inc. v. Nation Enterprises, 471 U.S. 539, 549 (1985). Extending an author's exclusive rights to the ideas embodied in her work would frustrate the creative enterprise, and impinge upon core First Amendment values by restricting the expression of ideas. Thus, the idea/expression 
of the idea/expression dichotomy, copyright law grants authors monopoly rights in the expression of the ideas embodied in their works, but withholds such monopoly protection from the underlying ideas themselves. ${ }^{147}$ Thus, for example, the copyright owner of the film Analyze This may prohibit subsequent filmmakers from copying substantial portions of scenes from the film or from appropriating detailed creative elements from the film, but cannot prohibit subsequent creators from building upon the idea of a Mafia boss experiencing panic attacks, seeking psychotherapy, the warring Mafia clans' response, etc. ${ }^{148}$ Similarly, the owner of the copyright in the film Star Wars can prohibit a subsequent filmmaker from creating a movie that incorporates and free rides upon substantial creative elements of Star Wars, but cannot lay exclusive claim to the idea of a movie involving intergalactic battles. ${ }^{149}$

Historically, the copyright statute did not specify which portions of creative works fell within and which fell without the scope of an author's monopoly. ${ }^{150}$ Yet, as

dichotomy ensures that the ideas embodied in copyrighted works can circulate freely, while granting copyright owners the right to control their particular expression of their ideas. See Jessica Litman, Reforming Information Law in Copyright's Image, 22 U. DAYTON L. REV. 587, 604 (1997). As Neil Netanel explains in his discussion of the role of copyright in a democratic society, in order for citizens to participate in a rich cultural, social, and political life, they must have wide latitude to express and reformulate ideas embodied in copyrighted expression. See Neil Netanel, Copyright in a Democratic Civil Society, 106 YALE L. J. 283 (1996). In the words of pragmatist philosopher John Dewey, in order for citizens to formulate and articulate their interests and preferences on public issues, they must "have access to the rich store of the accumulated wealth of mankind in ideas, knowledge, and purposes." JOHN DEWEY, LIBERALISM AND SOCIAL ACTION 52 (1963), quoted in Netanel, supra, at 349 \& n.302.

${ }^{147}$ Significantly, if an idea can only be expressed in one or a limited number of ways, copyright law resolves this issue of whether to extend protection to the idea and its expression in favor of the public, by refusing to grant copyright protection to expression that "merges" with the idea it embodies. See, e.g., Kern River Gas Transmission Co. v. Coastal Corp., 899 F.2d 1458 (5th Cir. 1990).

${ }^{148}$ The critically-acclaimed Home Box Office (HBO) series The Sopranos is premised upon the same basic characters and plot lines as Analyze This, but is a far superior work.

${ }^{149}$ See Twentieth Century Fox Film Corp. v. MCA, 715 F.2d 1327 ( $9^{\text {th }}$ Cir. 1983).

${ }^{150}$ Litman, supra note 138, at 978. 
copyright holders brought infringement actions seeking to exercise broad exclusive rights in their works in order to prohibit subsequent creators from building upon their works, the courts responded by developing the idea/expression dichotomy. ${ }^{151}$ Over the years, the courts developed a jurisprudence of limitations on authors' rights by articulating those aspects of copyrightable works that were properly subject to authors' exclusive control and those that were not. Largely through the vehicle of the idea/expression dichotomy, courts declined to allow authors to exercise exclusive control over the broad outlines of their plots, themes, characters, and literary devices. ${ }^{152}$

The famous Learned Hand opinion of Nichols v. Universal Pictures ${ }^{153}$ illustrates the judicial role in curtailing authors' rights in order to protect the interests of subsequent authors. The plaintiff in Nichols authored a play entitled Abie's Irish Rose, involving a Jewish family and an Irish Catholic family whose children fall in love, secretly marry, and raise a family. Plaintiff alleged copyright infringement by the author of the subsequently created play The Cohens and The Kellys, also involving a Jewish family and an Irish Catholic family whose children fall in love, secretly marry, and raise a family. Ruling on plaintiff's claim that his copyright was infringed because defendant's play borrowed the above-described broad plot lines, themes, and characters, Judge Learned Hand held that the elements appropriated by defendant were not properly within the scope of plaintiff's copyright. Rather, Judge Hand explained, such broad themes, stock characters, situations and plots were all no more than plaintiff's ideas, broadly speaking, which could not be privatized by plaintiff. Courts have also extended the

\footnotetext{
${ }^{151}$ See, e.g., id. ("When copyright owners brought lawsuits asserting broad claims of ownership, the courts took on the task of defining the nature of the rights in the copyright bundle. In so doing, they drew the contours of the public domain bit by bit.")

${ }^{152}$ Id. at 978-92.
} 
idea/expression dichotomy to other types of works of authorship, including technological works such as software programs, and have held that only the expression of ideas, but not the ideas embodied within the software, are protectible by copyright. ${ }^{154}$

In short, Congress and the courts have carved out several ideational components of copyrightable works and excluded these elements from the scope of authors' rights, and have in the process rejected authors' attempts to prohibit subsequent authors from building upon such components in creating their own works.

\section{Fair Use of Copyrighted Works}

Copyright law's fair use doctrine also serves to impose substantial limitations on authors' rights. While an author's copyright monopoly allows her to prohibit others from copying substantial portions of her work for competing commercial purposes, copyright law does not confer upon her the right to prevent others from copying her work (or portions thereof) for certain transformative, critical, and educational uses, among others. Over the years, in establishing the contours of the fair use doctrine, Congress and the courts ${ }^{155}$ have carved out a host of exceptions to the exclusive rights granted to authors, including exceptions for subsequent uses such as "criticism, comment, news reporting, teaching ..., scholarship or research." ${ }^{156}$ In applying a variation of the analysis of the interests and incentives operating upon authors in the original position, courts have

15345 F.2d 119 (1930).

${ }^{154}$ See, e.g., Computer Assocs. Int'1 v. Altai, Inc., 982 F.2d 693 (2d Cir. 1992).

${ }^{155}$ In 1976, Congress codified in Section 107 of the Copyright Act the judge-made fair use doctrine. See H.R. Rep. No. 101-514, $101^{\text {st }}$ Cong., 2d Sess. 22 (1990).

${ }^{156}$ See 17 U.S.C. $\S 107$. The Copyright Act also recognizes that the public interest warrants exceptions to authors' copyright monopolies in a number of areas that do not come under the aegis of the fair use doctrine. See 17 U.S.C. $\S \S 111(d), 115,118,119,122$ (compulsory licenses for cable retransmissions, phonorecords, public broadcasting, satellite retransmission); 17 U.S.C. $\S 105$ (exclusion of copyright protection for government works); and 17 U.S.C. $\S \S 108,110,121$ 
justified the fair use doctrine on a theory of hypothetical or implied consent. In justifying the limitations imposed on authors' rights by the fair use doctrine, for example, the Supreme Court explained in Harper \& Row that:

The author's consent to a reasonable use of his copyrighted works has always been implied by the courts as a necessary incident of the constitutional policy of promoting the progress of science and the useful arts, since a prohibition of such use would inhibit subsequent writers from attempting to improve upon prior works and thus frustrate the very ends sought to be attained [i.e., the promotion of the progress of science and the useful arts]. ${ }^{157}$

The fair use doctrine thus "permits courts to avoid rigid application of [the copyright holder's exclusive rights] where it would stifle the very creativity which the law is designed to foster." 158 Thus, under the fair use doctrine, if I were writing a book about the treatment of the mafia by Hollywood, I would likely be entitled under the fair use doctrine to incorporate a portion of the dialogue from the film The Godfather. If I were preparing a critical review or lampoon of Star Wars, I would be entitled to incorporate several clips from the film into my review.

It will be helpful for my purposes to classify types of fair uses into the following categories: (1) uses deemed fair because they are transformative and productive; (2) uses deemed fair in order to overcome earlier authors' desire to avoid criticism; and (3) uses deemed fair purely to overcome logistical barriers to market formation. An example of the first is a biographer's use of quotations from letters or journals written by the subject

(exemptions for library photocopying, certain public performances, reproduction for the blind and disabled).

${ }^{157}$ Harper \& Row, 471 U.S. at 539 (emphasis added).

${ }^{158}$ Iowa State Univ. Res. Found. v. ABC, 621 F.2d 57 (2d Cir. 1980). 
of the biography. ${ }^{159}$ The subsequent author's use of such quotations in creating her own work is transformative and advances copyright law's goals of promoting the creative process,${ }^{160}$ despite the fact that the copyright owner of the letters or journals might refuse to license their use. This category of fair uses also encompasses more diffusely transformative uses, like educational, research, and scientific uses, which ultimately tend to be transformative in that they lead to the promotion of the progress of science and the useful arts. An example of the second category is the fair use exception traditionally extended to works such as critical reviews and parodies that quote passages from the works they are criticizing. ${ }^{161}$ Because of the author's endemic refusal to license certain types of works that would reflect negatively upon her work - despite the fact that the subsequent use would advance the societal interest in the creative process - the fair use doctrine steps in to compel a (royalty-free) license between the author of the earlier work and the author of the subsequent work. ${ }^{162}$

An example of the third category of fair uses includes those types of uses that would likely be licensed if the earlier and later authors were brought to the bargaining table and negotiations over the terms of the use were facilitated. For example, if a commercial lecturer wished to prepare a handout that included a reproduction of one

${ }^{159}$ See, e.g., Wright v. Warner Books, 953 F.2d 731 (2d Cir. 1991) (biographer of novelist Richard Wright enjoyed fair use privilege to copy portions of Wright's letters and journals in creating biography).

${ }^{160} I d$. at 736 (holding that the biographer's copying of Wright's letters and journals "furthers the goals of the copyright laws by adding value to prior intellectual labor.")

${ }^{161}$ See, e.g., Campbell v. Acuff-Rose Music, 510 U.S. 569 (1994) (holding that 2 Live Crew's claimed fair use privilege to create rap parody of Roy Orbison song Oh, Pretty Woman was not defeated by rap version's commercial nature, and observing the "unlikelihood that creators of imaginative works will license critical review or lampoons" of their works.)

${ }^{162}$ As Wendy Gordon describes this category of fair uses, "[b]ecause the [author's] antidissemination motives make licensing unavailable in the consensual market, and because the free flow of information is at stake, a strong case for fair use can be advanced in these cases." Gordon, supra note 138, at 1633. 
paragraph from an obscure but copyright-protected journal, and if despite her efforts, the lecturer were unable to locate and secure permission from the copyright owner for such use, the fair use doctrine might be interpreted to permit such use. ${ }^{163}$ Because the lecturer's cost of transacting with the copyright owner over permission to reproduce the paragraph would likely exceed the benefits of transacting, ${ }^{164}$ in the absence of a privilege, such use would not go forward and society as a whole would be worse off. The fair use doctrine incorporates recognition of the fact that, because of such logistical impediments to negotiation and bargaining over such uses, unless such socially valuable subsequent uses were privileged, they would likely not take place. This third category of fair use thus reflects a fact about the state of the world in which transacting over non-substantial uses of prior works is often prohibitively expensive and time-consuming. The difference between the result reached by the fair use doctrine and that which likely would have been reached by an agreement between the parties is, of course, the absence of a licensing fee. Because this last category of fair uses is dependent upon the presence of transactions costs that impose logistical barriers to market formation -- primarily the cost of locating and negotiating with authors of prior creative works ${ }^{165}$-- to the extent that these types of transactions costs are reduced in the digital realm, ${ }^{166}$ the justifications for this type of fair use may not survive the migration of creative works to the digital realm.

${ }^{163}$ Cf. American Geophysical Union v. Texaco, 60 F.3d 913, 930-31 (2d Cir. 1995) (holding that reproductions of pages of journals for which photocopying license was readily available via Copyright Clearance Center was not fair use, but observing that "a particular unauthorized use should be considered 'more fair' when there is no ready market or means to pay for the use.") ${ }^{164}$ See, e.g., Richard A. Posner, When is Parody Fair Use?, 21 J. LEG. STUD. 67, 69 (1992).

${ }^{165}$ See, e.g., Gordon, supra note 138, at 1608-9.

${ }^{166}$ See, e.g., Merges, supra note 98, at 130. 
In short, copyright law imposes significant limitations on authors' exclusive rights in their works of authorship. By means of limitations on the term and scope of copyright protection, and the exceptions to authors' copyright monopoly carved out by the fair use doctrine, copyright law preserves for future authors the raw materials necessary to facilitate the creative enterprise in the long run. While protecting the ultimate harvest of an author's creative efforts, copyright law also protects "the seed and the substance of this harvest." ${ }^{167}$ Although the limitations on authors' rights are imposed primarily to advance copyright law's utilitarian purpose, these limitations also serve to mandate the savings of creative works for the benefit of future generations of authors and thus also advance concerns of intergenerational justice.

\section{Private ORdering of Rights in Creative Works}

The balance between rights granted to authors and the limitations on those rights traditionally embodied in copyright law is currently experiencing a tectonic shift, driven by forces from within and without copyright law. From within, copyright law was recently amended to provide a new type of right to copyright holders and to restructure the rights and privileges historically enjoyed by creators and members of the public. The Digital Millennium Copyright Act ${ }^{168}$ recognizes the right of authors to privately order their creative rights and to privately enforce these rights by means of technological measures -- such as encryption and password controls -- that control access to and copying of works. The Digital Millennium Copyright Act (DMCA) also grants authors the right to enforce these rights through the judicial system, should their private

${ }^{167}$ Harper \& Row, 471 U.S. at 539.

${ }^{168}$ Pub. L. No. 105-304, 112 Stat. 2860, Section 1 (short title). 
enforcement mechanisms fail. ${ }^{169}$ One important creative industry - the major motion picture industry - has begun to exploit its new rights under the DMCA and to employ technology to prohibit all unauthorized access to and copying of motion pictures released in DVD format. ${ }^{170}$ Reeling from its battles with Napster, the music industry is also starting to use encryption technology in an attempt to prevent digital music files from being copied. ${ }^{171}$ By using technological measures to prohibit unauthorized access to and copying of their works, the copyright owners of such films are curtailing the privileges historically enjoyed by members of the public under copyright law, as discussed below.

The historical balance between authors' rights and the limitations on these rights is also undergoing a substantial shift set into motion by forces outside copyright law, in the form of major revisions in the contract law regime governing the licensing of electronic works. Authors of such works are now able to expand their copyright and copyright-like rights, while contracting users' privileges, by means of contractual terms that bind all those making use of such works. ${ }^{172}$ E-book authors are increasingly using clickwrap licenses to create exclusive rights in their works, rights that admit of no limitations analogous to those imposed by copyright law. In one of the more extreme examples of private ordering in the digital realm, Glassbook's e-book version of Lewis Carroll's classic Alice's Adventures in Wonderland contained terms that prohibited the copying or printing of any of the text or the reading aloud from the text. ${ }^{173}$ Below I explore both technological and contractual private ordering mechanisms now available to

${ }^{169}$ See 17 U.S.C. $\S \S 1203$ and 1204, providing civil and criminal penalties for circumvention of technological measures.

${ }^{170}$ See, e.g., Universal City Studios v. Reimerdes, 111 F. Supp. 2d 294 (S.D.N.Y. 2000) [currently on appeal to the Second Circuit].

${ }^{171}$ [Add citations to most recent developments of the Secure Digital Music Initiative, etc.]

172 See text accompanying notes 224-45. 
authors for circumventing the limitations traditionally imposed on authors' rights under copyright law, as well as the consequences of such circumvention.

\section{A. The Digital Millennium Copyright Act and The Private Ordering of Rights in Creative Works}

In the early years of the digital age, certain authors of digital works were concerned that copyright law, as then constituted, would not be up to the task of controlling illegal copying of their works. These authors feared that, because of the ease with which copies could be made of digital works, copyright law would be ineffectual in controlling the widespread and near instantaneous copying of their works. ${ }^{174}$ One proffered solution to such problems was to enable authors to take matters into their own hands by the use of technological measures to control unauthorized access to and copying of their works in digital form, and to have their right to use such technological measures protected by law. These interests prevailed both in the national forum, as reflected in by the Clinton Administration's 1995 NII White Paper, ${ }^{175}$ as well as in the international forum, in the 1996 World Intellectual Property Organization (WIPO) Copyright Treaty. ${ }^{176}$ To implement the United States' obligations under the WIPO Copyright Treaty, in 1998 Congress passed the Digital Millennium Copyright Act, thereby enacting the "most sweeping revisions ever"177 to the Copyright Act of 1976.

\footnotetext{
${ }^{173}$ See http://www.pigdogs.org/art/adobe.html, visited August 8, 2001.

${ }^{174}$ See, e.g., William J. Clinton and Albert Gore, Jr., A Framework for Global Electronic Commerce (1995).

${ }^{175} I d$.

${ }^{176}$ The WIPO Copyright Treaty requires complying countries to afford "adequate legal protection and effective legal remedies against the circumvention of effective technological measures that are used by authors in connection with the exercise of their rights under this Treaty or the Berne Convention ...." WIPO Copyright Treaty, April 12, 1997, Art. 12, S. Treaty Doc. No. 105-17 (1997).

${ }^{177}$ David Nimmer, A Riff on Fair Use in the Digital Millennium Copyright Act, 148 U. PA. L. REV. 673, 674 (2000).
} 


\section{DMCA and The Private Ordering of Access Controls and Copy Controls}

Title I of the Digital Millennium Copyright Act essentially recognizes authors' rights to use technological measures to establish and enforce the terms on which their works can be accessed and copied (if at all), thereby countenancing authors' ability to privately order their rights in their works. The DMCA also grants authors the right to seek judicial recourse when and if their technological measures controlling access and copying are compromised. And in enforcing authors' new "paracopyright" right against circumvention of access control measures, courts are not permitted to take into account the traditional limitations on authors' rights imposed by the fair use doctrine. ${ }^{178}$ DMCA thereby creates a new copyright-like right for authors - the right to technologically control access to their work and to prohibit circumvention of such technologies -- and exempts this right from certain limitations traditionally imposed on authors' rights for the benefit of future authors.

In analyzing the operation of the provisions embodied in Section 1201 of the Digital Millennium Copyright Act, it will first be helpful to explore the distinction set forth in this section between what we may call "access control" devices ${ }^{179}$ and "copy control" devices. ${ }^{180}$ An access control device is a device, such as an encryption or

\footnotetext{
${ }_{178}^{178}$ See Nimmer, supra note 177 , at 739.

${ }^{179}$ See 17 U.S.C. $\$ 1201(\mathrm{a})(3)(B)$ (A "technological measure 'effectively controls access to a work' if the measure in the ordinary course of its operation, requires the application of information, or a process or a treatment, with the authority of the copyright owner, to gain access to the work.") (Emphasis added.)

${ }^{180}$ See $\S 1202$ (b)(2)(B) (A "technological measure "effectively protects a right of a copyright owner under this title' if the measure, in the ordinary course of its operation, prevents, restricts, or otherwise limits the exercise of a right of a copyright owner under this title.") (Emphasis added). By its terms, this definition is not restricted to copy control devices; rather, it extends to measures that protect any of the copyright holder's exclusive rights, including the right to copy, adapt, distribute to the public, or publicly perform or display. Some have argued that this definition incorporates fair use limitations, because the rights of a copyright owner, as set forth in Section 106, are expressly made subject to the limitations set forth in Section 107, Limitations on
} 
password system, that controls access to a copyrighted work. For example, the owner of the copyright in a motion picture might release the film for home viewing only on DVD and prohibit unauthorized access to the film stored on DVD by means of encryption technology. ${ }^{181}$ Or, the author of a novel might release it only in electronic form via the Internet and control access to the story by means of password controls. ${ }^{182}$ Both types of controls would be considered technological measures that effectively control access to a work, ${ }^{183}$ or "access control devices" for short. A copy control device is a device that restricts the reproduction of works protected by copyright ${ }^{184}$ (or which restricts the unauthorized exercise of another of the author's exclusive copyright rights). ${ }^{185}$ For example, the copyright owner of a film might release the film on DVD and use encryption or other technological measures to prohibit the copying of any part of the film. ${ }^{186}$ Such technology would be considered a technological measure that effectively protects the reproduction right of the copyright owner, or a "copy control" device for short. Section 1201 prohibits both (1) the circumvention of access control devices protecting a work, and (2) the making available to the public (and/or other types of "trafficking in") devices designed either to circumvent access controls or copy controls. As of October 28, 2000, Section 1201 prohibits three types of conduct: (1) circumventing

Exclusive Rights: Fair Use. See Jane C. Ginsburg, Copyright Legislation for the "Digital Millennium, " 23 COLUM.- VLA J.L. \& ARTS 137, 152 (1999).

${ }^{181}$ See, e.g., Reimerdes, 111 F. Supp. $2 \mathrm{~d}$.

${ }^{182}$ See text accompanying note 224.

${ }^{183}$ See 17 U.S.C. $\$ 1201(\mathrm{a})(3)(B)$.

${ }^{184}$ As explained infra, Section 1201 prohibits both the circumvention of technological measures controlling access to copyrighted works and technological measures prohibiting copying of copyrighted works.

${ }^{185}$ See 17 U.S.C. $\S 1201(b)(2)(B)$.

${ }^{186}$ See Reimerdes, 111 F. Supp. $2 \mathrm{~d}$ at 308. 
an access control device protecting a copyrighted work ${ }^{187}$; (2) "trafficking in" devices primarily designed to circumvent access controls ${ }^{188}$; (3) "trafficking in" devices primarily designed to circumvent copy controls. ${ }^{189}$

As an example of access and copy control devices used by authors to privately order their rights in their works, consider the measures recently taken by the motion picture industry in conjunction with distributing their films on DVD. Electing not to rely

18717 U.S.C. $§ 1201(a)(1)$ provides that "No person shall circumvent a technological measure that effectively controls access to a work protected under this title." Notably, Section 1201 does not prohibit circumventing a copy control device protecting a copyrighted work.

188 17 U.S.C. $\$ 1201(\mathrm{a})(2)$ provides that:

No person shall manufacture, import, offer to the public, provide, or otherwise traffic in any technology, product, service, device, component, or part thereof, that-

(A) is primarily designed or produced for the purpose of circumventing a technological measure that effectively controls access to a work protected under this title;

(B) has only limited commercially significant purpose or use other than to circumvent a technological measure that effectively controls access to a work protected under this title; or

(C) is marketed by that person or another acting in concert with that person with that person's knowledge for use in circumventing a technological measure that effectively controls access to a work protected under this title.

${ }^{189} 17$ U.S.C. $\S 1201(\mathrm{~b})(1)$ provides that

No person shall manufacture, import, offer to the public, provide, or otherwise traffic in any technology, product, service, device, component, or part thereof, that-

(A) is primarily designed or produced for the purpose of circumventing protection afforded by a technological measure that effectively protects a right of a copyright owner under this title in a work or a portion thereof;

(B) has only limited commercially significant purpose or use other than to circumvent protection afforded by a technological measure that effectively protects a right of a copyright owner under this title in a work or a portion thereof; or

(C) is marketed by that person or another acting in concert with that person with that person's knowledge for use in circumventing protection afforded by a technological measure that effectively protects a right of a copyright owner under this title in a work or a portion thereof. 
solely on copyright law's traditional prohibitions on unauthorized reproduction, public distribution and display, etc., of works of authorship, the industry supplemented its traditional copyright rights with technological measures prohibiting unauthorized access to and copying of all or any part of their films distributed on DVD. ${ }^{190}$ In making their films available on DVD, the motion picture distributors have employed an encryptionbased access control and copy prevention system, known as the Contents Scramble System (CSS), to control access to and prohibit the copying of all or any part of films distributed on DVD. ${ }^{191}$ When the CSS was subsequently compromised by a decryption program known as DeCSS, the film distributors successfully brought suit under Section 1201 of the DMCA against those who made DeCSS available to the public, in the case of Universal City Studios v. Reimerdes. ${ }^{192}$

The defendants in Reimerdes claimed that the distribution of a program that circumvented plaintiffs' access control and copy control devices was necessary to enable members of the public to exercise the fair use rights they have historically enjoyed. ${ }^{193}$ Defendants contended that plaintiffs' use of technological measures to assert unlimited exclusive rights in their works was inconsistent with the limitations on rights historically imposed under the Copyright Act. The Reimerdes court held, however, that because plaintiffs were not seeking vindication of their traditional - and traditionally limited copyright rights, but of their newly-created anti-circumvention rights under Section 1201 of the Copyright Act, the fair use doctrine did not serve to limit plaintiffs' rights in their

\footnotetext{
${ }^{190} I d$. at 308 .

${ }^{191}$ As the court explained in Reimerdes, "The application of CSS [the Contents Scramble System] to encrypt a copyrighted motion picture ... prevents exact copying of either the video or the audio portion of all or any part of the film." Id. at 322.

${ }^{192} I d$.

${ }^{193} I d$. at 321.
} 
works. ${ }^{194}$ Rejecting the argument that the use of the DeCSS decryption program was necessary to enable members of the public to exercise their fair use rights with respect to motion pictures stored in encrypted form on DVDs, the court held that the fair use doctrine did not provide a defense to a Section 1201 violation.

As the Reimerdes case demonstrates, authors can now employ technological measures in exercise of their rights under the Digital Millennium Copyright Act to prevent any and all copying of their works and to prohibit all but paid and licensed access to such works. And authors who employ such technological measures are entitled under Section 1201 to call upon the courts to protect their privately ordered rights when their technological measures of doing so fail. As scenarios like that presented in the Reimerdes case become more and more common, the issue is squarely raised of the continued significance of and need for the limitations that copyright law has historically imposed on authors' rights. Although Congress may have intended, in passing the DMCA, to "extend[] into the digital environment the bedrock principle of 'balance' in American intellectual property law for the benefit of both copyright owners and users,",195 it is far from clear that this intention was effectuated.

\section{The Digital Millennium Copyright Act and The Fair Use Doctrine}

An analysis of whether and how well the Digital Millennium Copyright Act extends into the digital realm the fair use rights and other traditional limitations on authors' exclusive rights is a complex one. In crafting the DMCA's anti-circumvention and anti-trafficking provisions and the exceptions thereto, Congress undertook efforts to preserve some types of fair uses for some types of communities in some types of works

${ }^{194} I d$. at 322.

195 See Report of the House Comm. on Commerce, H.R. Rep. No. 105-551, pt. 2, at 25-26 (1998). 
of authorship. First, several narrowly-crafted exceptions are available to Section 1201(a)(1)'s provision barring circumvention of access controls for certain "formal fair use communities." ${ }^{196}$ For example, Section 1201 grants non-profit libraries, archives, and educational institutions the right to circumvent access controls on copyrighted works solely in order to -- and only for as long as necessary to -- determine whether they wish to purchase a legitimate authorized copy of the access-controlled work. ${ }^{197}$ This exemption is only available if the access-controlled work is not reasonably available in another form. Thus, if a library sought to determine whether to purchase a copy of Stephen King's latest novel released in encrypted form on his web site, the library could lawfully circumvent such encryption access controls for so long as it took to determine whether it wished to purchase an authorized copy of the novel, only if the novel were not available in unprotected (hard copy) format, and, importantly, only if the means for circumventing such access controls were available to it. ${ }^{198}$

Second, Section 1201 grants users a right to circumvent access controls in order to reverse engineer a computer program, solely in order to identify and analyze the elements of the program necessary to achieve interoperability with other programs. ${ }^{199}$ Individuals are also permitted to develop (and "traffic in" ${ }^{200}$ ) technology to circumvent technological measures used to reverse engineer computer programs in order to achieve interoperability. ${ }^{201}$ Thus, in the special context of computer programs, users are granted the privilege of circumventing access controls in order to access the unprotectable ideas

\footnotetext{
${ }^{196}$ See Ginsburg, supra note 180 , at 153.

197 See 17 U.S.C. $\$ 1201(\mathrm{~d})$.

${ }^{198} \mathrm{Id}$.

${ }^{199}$ See 17 U.S.C. $\S 1201(f)$.

${ }^{200} 17$ U.S.C. $\$ 1201(f)(2)$.

${ }^{201} 17$ U.S.C. § 1201(f)(2),(3).
} 
embedded within the computer programs, ${ }^{202}$ and developers are granted the privilege of developing technologies to enable users to do so. Further, certain types of encryption research activities are exempted from the reach of the anti-circumvention provision, and the development of technology facilitating such research activities is exempted from the reach of the anti-trafficking provision, ${ }^{203}$ where such acts are conducted to advance the state of knowledge in the field of encryption. ${ }^{204}$

In addition to providing the above narrowly-circumscribed fair use exemptions in deference to formal fair use communities and in response to scientific research and development needs, Congress also embedded a "fail-safe" mechanism ${ }^{205}$ into Section 1201 with the intention of accommodating on an ongoing basis the fair use rights of a broader range of communities. Under this fail-safe mechanism, Section 1201(a)(1)'s prohibition on the circumvention of access controls will not apply to "persons who are users of a copyrighted work which is in a particular class or works if [the Librarian of Congress $^{206}$ determines that] such persons are, or are likely to be in the succeeding three year period, adversely affected by virtue of [the anti-circumvention] prohibition in their ability to make non-infringing uses of that particular class of works . ..."207 That is, if the Librarian of Congress determines that Section 1201's provisions prohibiting circumvention of access controls have or will likely have an adverse effect on users' ability to make non-infringing uses of a particular class of copyrighted works, the Librarian can exempt that class of works from the reach of the anti-circumvention

\footnotetext{
${ }^{202}$ See Sega v. Accolade, 977 F.2d 1510 (9 $9^{\text {th }}$ Cir. 1992).

${ }^{203} 17$ U.S.C. $\$ 1201(\mathrm{~g})(4)$.

${ }^{204} 17$ U.S.C. $\$ 1201(\mathrm{~g})$.

205 See Nimmer, supra note 177, at 692.

${ }^{206}$ The determination of the Librarian of Congress shall be made pursuant to a rule-making proceeding as prescribed in Section 1201(a)(1)(C).
} 
provision for three years. ${ }^{208}$ For example, if the Librarian of Congress were to determine that users of audiovisual operatic works were adversely affected by the anticircumvention provision, the Librarian could exempt this class of works from the provision's reach. Thus far, the Librarian has only exempted two very narrowly drawn classes of works from the reach of the anti-circumvention provision. ${ }^{209}$ Thus, for the vast majority of users and with respect to the vast majority of copyrighted works, no fair use limitations apply to Section 1201's anti-circumvention provision. ${ }^{210}$

Defenders of Section 1201's regime will note that this section only prohibits circumventing access control devices and does not prohibit circumventing copy control devices. If a user has or somehow gains access to a work subject to copy controls, she is not prohibited by Section 1201 from circumventing these copy controls -- assuming she has a technological means of doing so - in order to make fair use type copies of the work. Furthermore, Section 1201 specifically recognizes that "nothing in this section shall affect rights, remedies, limitations, or defenses to copyright infringement, including fair

\footnotetext{
207 17 U.S.C. $\$ 1201(\mathrm{a})(1)(\mathrm{B})$.

${ }^{208}$ See 17 U.S.C. $\$ 1201(\mathrm{a})(1)(\mathrm{D})$.

${ }^{209}$ See 65 Fed. Reg. 64555 (Oct. 27, 2000) (exempting (1) "compilations consisting of lists of websites blocked by filtering," and (2) "literary works, including computer programs and databases, protected by access control mechanisms that fail to permit access because of malfunction, damage or obsoleteness.")

${ }^{210}$ Furthermore, even with respect to works that are exempted under the fail-safe mechanism i.e., works for which users are not prohibited from circumventing their access controls - it is not at all clear that users will have any means at their disposal actually to circumvent the access controls guarding such works. Recall that Section 1201 also prohibits the trafficking in devices circumventing access controls. Because the trafficking in circumvention technology is prohibited by Section 1201(a)(2), access-control defeating technologies will generally not be made available, so the exemptions granted by the Librarian for certain types of works may be essentially meaningless. Furthermore, the trafficking in technology specifically designed to circumvent access controls controlling only works falling within an exempted class is not necessarily permitted under the statutory wording of Section 1201. See Nimmer, supra note 177, at 735-77.
} 
use, under this title."211 The Copyright Office, in its summary of the Digital Millennium Copyright Act, ${ }^{212}$ explains that the absence of a direct prohibition on circumventing copy controls to parallel the prohibition on circumventing access controls was intended "to assure that the public will have the continued ability to make fair use of copyrighted works. Since copying of a work may be a fair use under appropriate circumstances, Section 1201 does not prohibit the act of circumventing a technological measure that prevents copying." ${ }^{213}$ But, as discussed below, the privilege of circumventing copy controls will likely ring hollow: because the Act does prohibit trafficking in devices designed to circumvent copy controls, ${ }^{214}$ it is likely that users will not have sufficient means available to them to circumvent such copy controls and to exercise their privilege of making fair use copies.

To understand the effect of Section 1201's prohibitions, consider more closely the use of the Contents Scramble System by motion picture distributors to control unauthorized access to and copying of films released on DVDs in the context of the following scenarios: (1) Scenario One: in 2001, several blockbuster hits are released only on DVDs protected by the Contents Scramble System; (2) Scenario Two: the classic Charlie Chaplin film The Tramp, which has fallen into the public domain, is released on CSS-protected DVD with a new (and copyright-protected ${ }^{215}$ ) introduction; and (3) Scenario Three: a never before released Charlie Chaplin film from 1922 is released (with a new introduction) only on CSS-protected DVD. Below I explore the effect of Section

${ }^{211} 17$ U.S.C. $\$ 1201(\mathrm{c})$.

${ }^{212}$ U.S. Copyright Office Summary, The Digital Millennium Copyright Act of 1998 (Dec. 1998). ${ }^{213} I d$. at 4.

${ }^{214}$ See 17 U.S.C. $\S 1201(b)(1)$. 
1201's prohibitions on a hypothetical cinema professor, Carla, who seeks to exercise her traditional fair use rights with respect to the films in each of these scenarios.

With respect to Scenario One, Carla wishes to conduct a lecture on the blockbuster hits of 2001, including those released only on DVD, and to create an associated montage of relevant clips from such films. Is it possible, as a technological and as a legal matter, for her to do so? First, although she is not prohibited by Section 1201 from circumventing the DVD's copy controls to copy portions of films stored on DVD, she is prohibited by Section 1201(a)(1) from circumventing the DVD's access controls. Software such as DeCSS which defeats the Contents Scramble System circumvents both its access and copy controls; ${ }^{216}$ therefore, it is illegal to make such technology available to the public under Sections 1201(a)(2) and 1201(b)(1). ${ }^{217}$ But let us suppose that Carla had a compliant DVD player and a legitimate DVD of each film from which she wishes to copy in creating her montage, so that she need not circumvent the CSS access controls. Would she be able to defeat CSS's copy controls in order to make fair use copies of the blockbuster films released only on DVD? As a legal matter, under 1201, the answer is yes; Section 1201 does not prohibit the circumvention of copy controls. As a practical matter, the answer is, probably not. In order to defeat CSS's copy controls and make a digital copy of portions of the films stored on DVD, she would need some technological means of circumventing these copy controls. But it is illegal to "traffic in" technology that circumvents copy controls. ${ }^{218}$

\footnotetext{
${ }^{215}$ See, e.g., Nimmer, supra note 177, at 712 ("Publishers are free to take old works that have fallen into the public domain, to add a bit of original material to them and to claim a copyright in the newly-released whole.")

${ }^{216}$ See Reimerdes, 111 F. Supp. 2d at 308.

${ }^{217}$ See id. at 316 n.133.

${ }^{218}$ More precisely, it is illegal to traffic in any technology that
} 
If Carla cannot legally secure technology to circumvent CSS's copy controls so as to make digital copies of portions of the films stored on DVD, her only alternative for making fair use copies of the DVDs would be to develop such circumvention technology herself. Recall that it is only a violation to traffic in such copy-control defeating technology, not to use such copy-control defeating technology (and presumably, not to create such technology for one's own use). But it is highly unlikely that Carla and those similarly situated will be able to develop such sophisticated encryption technologydefeating technologies by themselves. Thus, the net effect of Section 1201's prohibitions is to leave users like Carla who are not technologically sophisticated enough to create their own circumvention devices with no means of exercising their traditional fair use rights with respect to works protected by copy-control devices. As the Reimerdes court explained in ruling on the applicability of the fair use defense to defendant's Section 1201 violation, in enacting the DMCA, "Congress elected to leave technologically unsophisticated persons who wish to make fair use of encrypted works without a means of doing so." 219

(A) is primarily designed or produced for the purpose of circumventing protection afforded by a technological measure that effectively protects a right of a copyright owner under this title in a work or a portion thereof;

(B) has only limited commercially significant purpose or use other than to circumvent protection afforded by a technological measure that effectively protects a right of a copyright owner under this title in a work or a portion thereof; or

(C) is marketed by that person or another acting in concert with that person with that person's knowledge for use in circumventing protection afforded by a technological measure that effectively protects a right of a copyright owner under this title in a work or a portion thereof.

17 U.S.C. § 1201(b)(1).

${ }^{219}$ Reimerdes, 111 F. Supp. 2d at 323. 
It might be responded that Carla should not complain because and to the extent that she can always make non-digital fair uses of the films released exclusively on DVDs. For example, she could simply transcribe, or make an analog audio copy from the speaker output of, the dialogue she wishes to lecture on, or she could take a still picture or analog video tape of the monitor of the DVD player, etc. As the Reimerdes court observed, "of course, one might quote the verbal portion of the soundtrack, rerecord both verbal and non-verbal portions of the soundtrack [of a copy-controlled DVD], and videotape or otherwise record images produced on a monitor when the DVD is played on a compliant DVD player." ${ }^{220}$ Such limited privileges, however, fail to secure for Carla the right to make digital fair uses of creative works. In essence, the fair use privilege that is preserved for Carla and users like her in the digital realm is the privilege of making analog uses of digital works, a privilege that will ring hollow with the progressive migration of creative works to the digital realm.

The end result of Section 1201's prohibitions on the act of circumvention and on the "trafficking in" circumvention technologies is that prospective authors will essentially be prohibited from making digital fair uses of technologically-protected works of authorship, and will be unable to carry forth into the digital realm the fair use rights that they have historically enjoyed in the pre-digital realm. In passing the DMCA in an effort to prevent the unfair copying of digital works, Congress also has essentially prohibited the fair copying of digital works protected by technological measures.

Next consider Scenarios Two and Three, in which Carla wishes to exercise the privileges traditionally granted to her by copyright law with respect to the public domain Chaplin films released, each with a new introduction, on a CSS-protected DVD. Because

${ }^{220} I d$. at 322 n. 160 . 
the underlying films themselves are no longer protected by copyright, Carla enjoys the legal right under the Copyright Act to make whatever uses she pleases of the films. But because the films, packaged with their added introductions, are protected by copyright ${ }^{221}$ and because the DVDs on which the films are stored are protected by copy control devices, under the analysis set forth above, Carla would be unable to make any digital copies of the film and would be required to resort to making analog copies or copying an analog version of the film - if one is available to her. This is especially troubling with respect to Scenario Three, where the encrypted digital version of the film is the only version available. By combining a copyrightable introduction with a public domain work, and then locking up the combined work with access and copy control devices, an "author" can create virtually unlimited exclusive rights in a largely uncopyrightable work. Furthermore, the copyright holder in the Chaplin film can use technological measures to parlay a copyright of limited term into a perpetual right, merely by adding a new introduction at the end of each copyright term and then locking up the entire work using access control and copy control devices.

In short, technological measures countenanced by the Digital Millennium Copyright Act used to control access to works of authorship, coupled with the Act's prohibitions on trafficking in technology that defeats access and copy control devices, render fair use limitations on creators' rights in technologically-protected digital works essentially meaningless. Furthermore, the Act's anti-circumvention and anti-trafficking provisions enable such creators to parlay their durationally limited copyright rights into unlimited rights in their works. Even though the Digital Millennium Copyright Act creates exceptions for certain fair use communities and for certain types of fair uses, and

${ }^{221}$ See, e.g., Nimmer, supra note 177 , at 712. 
even though the act of circumventing copy control devices is technically not prohibited, the Act's anti-trafficking provisions will operate to prohibit most users from exercising their right to circumvent copy control devices in order to make fair use copies of technologically-protected works and in order to access public domain elements of creative works. Section 1201 's countenance of the use of technological measures to control access to and copying of works, coupled with its ban on trafficking in circumvention technology, will render users who are not encryption software developers $^{222}$ unable to make fair use digital copies of works or to use the portions of such works that are unprotected by copyright. Despite the asserted intentions of its drafters, ${ }^{223}$ the Digital Millennium Copyright Act fails to carry forth into the digital realm the limitations on authors' rights historically imposed by copyright law. Instead, the DMCA essentially freezes future authors' ability to exercise fair use rights within the analog realm, prevents them from exercising their fair use rights within the digital realm, and enables present authors to circumvent the durational limits imposed on copyright rights.

\section{B. Contractual Measures and Private Ordering of Rights in Creative Works}

In addition to using technological measures to control access to and copying of their works, authors of digital works are also turning to contractual measures to privately order their rights. For example, authors of electronic books are resorting to contractual measures to establish virtually unlimited rights in their works. Authors such as Stephen King are using contractual measures to control uses of their own works, while others are

\footnotetext{
${ }^{222}$ See, e.g., id. at 739-40 ("If the courts apply Section 1201 as written, the only users whose interests are truly safeguarded are those few who personally possess sufficient expertise to counteract whatever technological measures are placed in their path.”)
} 
using such measures to create for themselves rights in public domain works. Glassbook's e-book of Lewis Carroll's classic Alice's Adventures in Wonderland, for example, comes with terms prohibiting the copying, printing, or reading aloud of the work. ${ }^{224}$ The use of such contractual measures, like the use of technological measures, enables authors to create rights in their works that are not subject to the limitations historically imposed by copyright law to advance the societal creative process and to protect the interests of future authors. Because the topic of shrinkwrap and clickwrap licenses has been explored elsewhere in the literature, ${ }^{225}$ I will not reiterate the arguments for and against the enforcement of such license terms here, but will instead briefly outline the salient features of such licenses and examine the ways in which they can be used to establish rights in creative works that are not subject to the limitations historically imposed by copyright law.

Shrinkwrap or clickwrap licenses are licenses that establish the terms and conditions for the use of electronic works. For example, in acquiring a software program $^{226}$ or a work of literature ${ }^{227}$ over the Internet, a user will likely be required to agree to the terms and conditions established by the author of such works as a prerequisite to her purchase and use of the work. The terms of such licenses typically augment the author's rights and limit the purchaser's privileges relative to those enjoyed

\footnotetext{
${ }^{223}$ See text accompanying note 195 .

${ }^{224}$ See http://www.pigdogs.org/art/adobe.html, visited August 8, 2001.

${ }^{225}$ See, e.g., Mark Lemley, Beyond Preemption: The Law and Policy of Intellectual Property Licensing, 87 CALIF. L. REV. 111 (1999); Michael Madison, Legal-Ware: Contract and Copyright in the Digital Age, 67 ForD. L. REV. 1025 (1998); David Nimmer, et al., The Metamorphosis of Contract into Expand, 87 CALIF. L. REV. 17 (1999); Pamela Samuelson, Intellectual Property and Contract Law for the Information Age, 87 CALIF. L. REV. 1 (1999). ${ }^{226}$ See ProCD v. Zeidenberg, 86 F.3d 1447 (7 $7^{\text {th }}$ Cir. 1996).

${ }^{227}$ See text accompanying note 173 .
} 
by the parties under copyright law. ${ }^{228}$ For example, the license terms may prohibit users from making fair use type copies of the work, ${ }^{229}$ or from copying portions of the work that are unprotectable by copyright, such as the facts or ideas contained within the work or, in the case of public domain works, from copying the entire underlying work itself. ${ }^{230}$ The license terms may also purport to extend such rights in perpetuity, ${ }^{231}$ in contrast to the limited duration of rights granted to authors under copyright law. Such license terms, if embedded within the subject works, must be confronted and assented to before accessing such works, and are therefore binding upon all those who subsequently make use of such works. For example, the developer of a software program might embed a license within the program itself so that anyone who operates the program is first made to agree to the custom license terms governing its use, terms that may prohibit users from accessing the unprotectable ideas embodied in such works or forbid the reproduction of other components of the work that are unprotected by copyright, such as facts or data. ${ }^{232}$ Interestingly, the Contents Scramble System - the encryption software program used to control unauthorized access to and copying of films stored on DVDs - is itself governed by an electronic license that prohibits users from accessing and copying elements of the program that are unprotected by copyright or from exercising their fair use rights with respect to the program. ${ }^{233}$ And, although contractual provisions generally have limited effect in that they bind only those who are parties to the contract, in the case of embedded licenses, there are no relevant non-parties to such licenses, no users of the licensed works

\footnotetext{
${ }^{228}$ See, e.g., Nimmer, supra note 177.

${ }^{229} I d$.

${ }^{230}$ See ProCD, 86 F.3d at 1448.

${ }^{231}$ See text accompanying note 244 .

${ }^{232}$ See, e.g., ProCD, 86 F.3d at 1448.
} 
who are not also bound by the relevant license terms. Given the embedded nature of such licenses, any user is first made to confront and assent to the terms of the embedded license.

Clickwrap licenses, unlike technological protection measures, are not selfenforcing and therefore the rights created by such licenses must be enforced by the courts, which have the discretion to refuse to enforce license terms that are overreaching, inconsistent with fundamental public policies, or that stand as obstacles to the achievement of copyright law's objectives. ${ }^{234}$ Thus far, however, courts have been largely sympathetic to efforts by authors to expand their rights via contract. The Seventh Circuit's analysis in ProCD v. Zeidenberg is illustrative of courts' willingness to uphold shrinkwrap license terms that eviscerate the limitations on authors' rights traditionally imposed by copyright law. ProCD involved the enforceability of a clickwrap license embedded within a software package that contained a database of telephone listings. The terms of ProCD's embedded license prohibited the reproduction and distribution of the elements of the phone directory, even though such elements - because purely factual -were unprotected by copyright. ${ }^{235}$ Zeidenberg, who had purchased and used the software and was therefore required to have assented to its license terms, nevertheless went on to copy and distribute the contents of the directory in a networked environment in violation

${ }^{233}$ See, e.g., DVD Copy Control Assoc. v. McLaughlin, Defendant's Memorandum of Points and Authorities in Opposition to Order to Show Cause re Preliminary Injunction.

${ }^{234}$ See Calif. Fed. Sav. Loan Ass'n v. Guerra, 479 U.S. 273, 280 (1987). See also Robert P. Merges, Expanding Boundaries of the Law: Intellectual Property and the Costs of Commercial Exchange: A Review Essay, 93 MicH. L.REV. 1570, 1613 (1995) ("Standard form licensing contracts, by virtue of their very uniformity and the immutability - in other words, nonnegotiability - of their provisions, have the same generality of scope as the state legislation that is often the target of federal preemption.") The Copyright Act also contains a statutory preemption provision. See 17 U.S.C. $§ 301$.

${ }^{235}$ See, e.g., Feist v. Rural Tel. Serv. Co., 499 U.S. 340 (1991). 
of the license. ${ }^{236}$ In response to ProCD's breach of contract argument, Zeidenberg asserted that the subject license terms were preempted by the Copyright Act, which preempts the enforcement of property-like rights that are equivalent to any of the exclusive rights granted by the Copyright Act. ${ }^{237}$ The district court credited Zeidenberg's argument and held that the license essentially purported to create for ProCD the exclusive and unlimited right to reproduce and distribute the work, in contravention of copyright law's preemption provision. ${ }^{238}$ The Seventh Circuit, however, ruled that the license merely created a bilateral contract right, not a property-like right, and that therefore the license was not rendered unenforceable by the force of copyright law's preemption provision. ${ }^{239}$

The Seventh Circuit's ruling in ProCD misunderstands the nature of embedded licenses and fails to appreciate that embedded licenses can be used to create rights against the relevant world that are in conflict with the limited rights granted to authors by copyright law. In attempting to distinguish between property rights created by the Copyright Act and contract rights created by the license governing the program at issue, the court observed that "someone who found a copy of [the program] on the street would not be affected by the shrinkwrap license." ${ }^{240}$ But in setting forth this hypothetical, the court failed to appreciate that the license at issue was embedded within the software. Upon inserting the software in one's disk drive, the first screen that came up would require the user to assent to the license terms prohibiting such copying or to exit the

\footnotetext{
${ }^{236}$ See ProCD, 86 F.3d at 1448.

${ }^{237}$ See id. (construing copyright law's statutory preemption provision, set forth at 17 U.S.C. $\S$ 301).

${ }^{238}$ ProCD v. Zeidenberg, 908 F. Supp. 640 (W. D. Wis. 1996).

${ }^{239}$ ProCD, 86 F. 3d 1447, 1453-54.

${ }^{240} I d$. at 1453.
} 
program. Although it is ordinarily the case that a third party to a contract is not bound by the license's terms - and that if the original licensee were to give the software to a stranger on the bus, the stranger would not be bound by the license terms - the same does not hold true of the embedded license scenario. Absent tampering with the embedded license - which would be illegal ${ }^{241}$ - there are no strangers to such license terms: all who use such works are bound by its terms. Thus, embedded contractual measures used by authors to privately order their rights in their works create property-like rights that are good against the (relevant) world, rights which may well conflict with the limited rights in creative works traditionally granted to authors under copyright law.

Legislatures are following the lead of courts in their willingness to countenance authors' use of clickwrap licenses to create unlimited rights for themselves. The much-


instantiation of the much-criticized ${ }^{243}$ proposed Article $2 \mathrm{~B}$ of the Uniform Commercial Code, provides a comprehensive set of default rules that enable authors of "informational works" - including works protected by copyright - to use licenses to create rights for themselves that are not subject to copyright law's traditional limitations on authors' rights. For example, authors of certain works are permitted under UCITA's scheme to create perpetual rights in their works. ${ }^{244}$ And while clickwrap license terms that violate "fundamental public policies" are supposedly subject to a heightened unconscionability

\footnotetext{
${ }^{241}$ Under 17 U.S.C. $§ 1202$, tampering with the embedded license would constitute illegal alteration of copyright management information.

${ }^{242}$ See, e.g., Pratik A. Shah, The Uniform Computer Information Transactions Act, 15 BERK. TECH. L.J. 85 (2000).

${ }^{243}$ See generally Symposium, Intellectual Property and Contract Law for the Information Age: The Impact of Article $2 B$ of the Uniform Commercial Code on the Future of Information Commerce, 87 CALIF. L. REV. 1 (1999).

${ }^{244}$ See UCITA $\S 308$ (default term for certain software and other licenses is in perpetuity).
} 
standard, ${ }^{245}$ it is uncertain whether courts will use such a standard to render unenforceable license terms requiring users to forgo their fair use rights or rights to access ideas or other elements of licensed works that are unprotectible by copyright.

In sum, technological measures, such as access-control and copy-control devices that prohibit the reproduction of all or any part of creative works, along with contractual measures, such as clickwrap licenses, that require users to forgo the right to make fair uses of works or to reproduce unprotected elements in creative works, threaten to erode the limitations that copyright law has traditionally imposed on authors' rights to advance the societal creative process and to safeguard the interests of future authors.

\section{ENFORCING INTERGENERATIONAL JUSTICE B ETWEEN AUTHORS：BUILDING Limitations BaCk INTO AUthors’ Privately ORdered Rights}

As I established in Parts I and II, concerns of intergenerational justice between authors justify mandating the "savings" of certain aspects of creative works for the benefit of future authors, where the "savings" of such works is translated into limitations on authors' rights. Deliberating behind a Rawlsian veil of ignorance, authors who had obscured from them information as to which creative generation they would belong upon leaving the original position would opt for a system of limited rights in creative works. Authors deliberating under such conditions would conclude that the imposition of such limitations is necessary to ensure that all generations of authors have available to them the raw materials required to exercise their creative rights. Copyright law over the centuries has come to embody limitations on authors' rights that approximate the savings of creative works that would be adopted by authors deliberating in the original position,

${ }^{245}$ See, e.g., Mary Jo Howard Dively and Carlyle C. Ring, Overview of Uniform Computer 
taking into account the interests and incentives operating upon authors in both earlier and later creative generations.

The private ordering of authors' rights -- via technological measures under the new Digital Millennium Copyright Act and via contractual measures increasingly upheld by the courts -- fails to carry over into the digital realm the limitations that are justified under the intergenerational justice analysis. As set forth in Section II(A) above, authors deliberating behind a veil of ignorance, who knew not which creative generation they would belong to and who would therefore wish to preserve for all authors the raw materials necessary to create, would opt for several types of limitations on authors' rights. In particular, authors deliberating behind the veil would adopt a savings principle (1) that would permit future authors to make use of the essential raw materials of the creative process, including ideas and ideational elements embodied in creative works; (2) that would permit future authors to make transformative uses even of the nonideational elements of creative works; (3) that would permit future authors to make evaluative uses of creative works; and possibly (4) that would impose durational limits on rights in creative works. ${ }^{246}$

Courts called upon to enforce rights in creative works established via technological and contractual measures should recognize the continued importance of

Information Transactions Act, 618 PLI/P AT. 113, 125 (2000).

${ }^{246}$ Other types of limitations on authors' rights traditionally imposed by copyright law, such as fair use privileges solely justified under a transactions costs analysis, may or may not be justified in the digital realm, depending upon whether the digital realm's promise of reduced transactions costs is fulfilled. To the extent, for example, that copyright law permits the fair use of a prior creative work because of high search costs, tracing costs, or similar transactions costs that impose logistical barriers to a later author's negotiation with an earlier author, the royalty-free licenses mandated under copyright law's fair use doctrine may no longer be justified in the digital realm. But the justifications for other types of fair uses - including transformative and evaluative uses of earlier works - survive the migration of works to the digital realm. 
limiting authors' rights for the benefit of future authors in the private ordering regime as they have in the publicly ordered copyright regime. Toward that end, the right granted to authors under Section 1201 of the Digital Millennium Copyright Act to prohibit the circumvention of technological measures used to control access to creative works should be limited in the interests of future generations of authors. Courts should construe the Section 1201 right to control access to one's work to be subject to the four types of limitations on authors' rights identified above. Specifically, courts should carve out a fair use type exception for those who circumvent technological protection measures in order to access the ideational components of protected works, to make transformative or evaluative uses of such works, or to access components of the works that are unprotectible by copyright. Second, courts should construe Section 1201's prohibitions on trafficking in access-control and copy-control defeating technologies to permit the making available of technologies to facilitate the circumvention of access-control and copy-control devices where necessary to allow users to access ideas and ideational elements embodied in such works, to allow users to make transformative or evaluative uses of such works, and to allow users to access the public domain content contained within technologically protected works.

Finally, courts construing contractual measures that expand authors' rights relative to the rights granted under copyright law should strike down provisions that stand as obstacles to the enforcement of copyright law's objectives - viz., promoting the progress of science and the useful arts and advancing the societal creative process by protecting the interests of future generations of authors. In states implementing the UCITA, courts should construe UCITA's "violation of public policy" language broadly 
to strike down contractual provisions that fail to preserve for future authors the raw

materials of the creative process or that are otherwise not limited in accordance with the intergenerational justice analysis set forth above. 